\title{
Acute Hyperbaric Oxygenation, Contrary to Intermittent Hyperbaric Oxygenation, Adversely Affects Vasorelaxation in Healthy Sprague-Dawley Rats due to Increased Oxidative Stress
}

\author{
Zrinka Mihaljević (D), Anita Matić, Ana Stupin, Lidija Rašić, Ivana Jukić, \\ and Ines Drenjančevićc
}

Department of Physiology and Immunology, Faculty of Medicine, Josip Juraj Strossmayer University of Osijek, Cara Hadrijana 10E, 31000 Osijek, Croatia

Correspondence should be addressed to Ines Drenjančević; ines.drenjancevic@mefos.hr

Received 19 July 2017; Revised 27 October 2017; Accepted 15 February 2018; Published 29 April 2018

Academic Editor: H. P. Vasantha Rupasinghe

Copyright (C) 2018 Zrinka Mihaljević et al. This is an open access article distributed under the Creative Commons Attribution License, which permits unrestricted use, distribution, and reproduction in any medium, provided the original work is properly cited.

\begin{abstract}
The present study was aimed at assessing endothelium-dependent vasorelaxation, at measuring superoxide production in the aorta and femoral artery, and at determining antioxidative enzyme expression and activity in aortas of male Sprague-Dawley rats $(N=135)$, randomized to an $\mathrm{A}-\mathrm{HBO}_{2}$ group exposed to a single hyperbaric oxygenation session $\left(120^{\prime}\right.$ of $100 \% \mathrm{O}_{2}$ at 2.0 bars), a $24 \mathrm{H}-\mathrm{HBO}_{2}$ group (single session, examined $24 \mathrm{~h}$ after exposure), a $4 \mathrm{D}-\mathrm{HBO}_{2}$ group (4 consecutive days of single sessions), and a CTRL group (untreated group). Vasorelaxation of aortic rings in response to acetylcholine (AChIR) and to reduced $\mathrm{pO}_{2}$ (HIR) was tested in vitro in the absence/presence of NOS inhibitor L-NAME and superoxide scavenger TEMPOL. eNOS, iNOS, antioxidative enzyme, and NADPH oxidase mRNA expression was assessed by qPCR. Serum oxidative stress markers and enzyme activity were assessed by spectrometry, and superoxide production was determined by DHE fluorescence. Impaired AChIR and HIR in the A-HBO 2 group were restored by TEMPOL. L-NAME inhibited AChIR in all groups. Serum oxidative stress and superoxide production were increased in the $\mathrm{A}-\mathrm{HBO}_{2}$ group compared to all other groups. The mRNA expression of iNOS was decreased in the A- $\mathrm{HBO}_{2}$ and $24 \mathrm{H}-\mathrm{HBO}_{2}$ groups while SOD1 and 3 and NADPH oxidase were increased in the $4 \mathrm{D}-\mathrm{HBO}_{2}$ group. The expression and activity of catalase and glutathione peroxidase were increased in the $4 \mathrm{D}-\mathrm{HBO}_{2}$ group as well. AChIR was $\mathrm{NO}$ dependent. Acute $\mathrm{HBO}_{2}$ transiently impaired vasorelaxation due to increased oxidative stress. Vasorelaxation was restored and oxidative stress was normalized $24 \mathrm{~h}$ after the treatment.
\end{abstract}

\section{Introduction}

Hyperbaric oxygenation $\left(\mathrm{HBO}_{2}\right)$ is commonly used to improve injuries related to hypoxia and ischemia, including infections, such as meningococcal sepsis and gaseous gangrene $[1,2]$, myocardial infarction [3], cerebral ischemia [4], and even some neurodegenerative disorders [5-7]. Experimental [8] and clinical data suggest that intermittent $\mathrm{HBO}_{2}$ [9] decreases tissue edema, increases nitric oxide (NO) synthesis, changes vascular reactivity to stimuli [10], and inhibits neuroinflammatory factors' expression and apoptotic pathways [11].
Oxygen is a highly reactive molecule which, at high partial pressures (like in $\mathrm{HBO}_{2}$ ), can contribute to the increased formation of reactive oxygen species (ROS) [12] and affect system hemodynamics and vascular function. However, emerging data suggest that whether the ROS would be produced depends on hyperbaric protocol [13-18]. For example, our previous study showed that acute exposure to $\mathrm{HBO}_{2}$ increased plasma oxidative stress (measured by lipid peroxidation products), decreased systolic and diastolic blood pressure, decreased $\mathrm{pH}$ and $\mathrm{pCO}_{2}$ in arterial blood, and increased $\mathrm{pO}_{2}$ in healthy $\mathrm{SD}$ rats [19]. On the other hand, intermittent $\mathrm{HBO}_{2}$ restored vascular relaxation [20] and changed 
the metabolic pathways involved in the vasorelaxation in healthy and diabetic animals. However, it did not affect oxidative stress markers which were persistently increased in $\mathrm{DM}$ rats [10]. Taken together, $\mathrm{HBO}_{2}$ may influence functional and structural characteristics of blood vessels, depending on the application protocol.

Antioxidant systems counter-effect the damage induced by ROS. That includes antioxidative enzymes, such as glutathione peroxidase, superoxide dismutase, or catalase [21]. On the other side, there is the nonenzymatic intracellular and extracellular antioxidant defense system [22] which includes different chemical groups, for example, vitamins, carotenoids, amino acids, and peptides, established in various cellular structures. All antioxidant factors of the body, either intracellular enzymes or antioxidant compounds (nonenzymatic factors), are called total antioxidant capacity. In a study conducted by Winston et al., it was revealed that glutathione, ascorbic acid (vitamin C), uric acid, and vitamin E compose $70 \%$ of the total antioxidant capacity of the body [23]. At the moment, only few studies examined the effect of $\mathrm{HBO}_{2}$ treatment on antioxidative defense capacity [21, 24-26], which may be an important modulator of diverse effects of acute and chronic or intermittent hyperoxygenation. We have found that plasma antioxidant capacity has not been affected by intermittent $\mathrm{HBO}_{2}$ protocol in diabetic rats [10].

Thus, the purpose of this study was to test the hypothesis that acute $\mathrm{HBO}_{2}$ leads to increased superoxide production, which underlies impaired endothelium-dependent vasorelaxation, in contrast to the effects of repeated exposures to $\mathrm{HBO}_{2}$ (intermittent $\mathrm{HBO}_{2}$ ), which is beneficial for the vasorelaxation in healthy rats. The experiments conducted in the present study were designed to (1) test the effect of $\mathrm{HBO}_{2}$ on vascular endothelial-dependent reactivity in healthy rats exposed to acute $\left(\mathrm{A}-\mathrm{HBO}_{2}\right), 24 \mathrm{~h}$ after a single exposure $\left(24 \mathrm{H}-\mathrm{HBO}_{2}\right)$ and intermittent $\mathrm{HBO}_{2}\left(4 \mathrm{D}-\mathrm{HBO}_{2}\right)$ compared to untreated healthy rats (CTRL) in regard to oxidative stress; (2) assess in situ aortic and femoral artery superoxide production of rats exposed to hyperbaric oxygenation; and (3) determine the expression of antioxidative enzymes in rat aortic tissue after various hyperbaric oxygenation protocols.

\section{Materials and Methods}

2.1. Experimental Animals. The animals were bred and housed at the animal care facility of the Faculty of Medicine Osijek. All experimental procedures conformed to the European Guidelines for the Care and Use of Laboratory Animals (directive 86/609) and were approved by the local and national Ethical Committee (no. 2158/61-02-139/2-06).

A total of 135 male Sprague-Dawley (SD) rats (age 9-12 weeks) were used in this study. Rats were housed in a temperature- $\left(21^{\circ} \mathrm{C}-23^{\circ} \mathrm{C}\right)$, humidity-, and light-controlled room with free access to tap water and fed ad libitum with a commercially prepared pellet diet (Mucedola, Italy).

2.2. Hyperbaric Oxygen $\left(\mathrm{HBO}_{2}\right)$ Treatment. Hyperbaric groups underwent single $\left(\mathrm{A}-\mathrm{HBO}_{2}\right.$ and $24 \mathrm{H}-\mathrm{HBO}_{2}$ groups) or four (one per day, intermittent, $4 \mathrm{D}-\mathrm{HBO}_{2}$ ) 120-minute sessions of $100 \% \mathrm{O}_{2}$ at 2.0 bars absolute of pressure with additionally 15 minutes for gradual compression and decompression (Recompression Chamber for Experiments 110L, Djuro Djakovic, Aparati d.d., Slavonski Brod, Croatia).

2.3. Blood Pressure Measurements: Surgical Procedure and Sample Collection. Invasive blood pressure measurement was done by a procedure described by Drenjancevic et al. [19]. Shortly, the left femoral artery was cannullated in anaesthetized rat. Body temperature was maintained constant during the measurement, and blood pressure was monitored with a Spacelabs Medical monitor system (Spacelabs Medical Inc., Redmond, WA, USA). The systolic and diastolic blood pressure was determined after 10 minutes of stabilization as average blood pressure recorded within one minute of measurement every 10 seconds. The mean arterial pressure (MAP) was calculated as the sum of the systolic blood pressure and double diastolic blood pressure divided by 3 . The same rats were used to collect aortas and arterial blood serum samples for further analysis of oxidative stress and $\mathrm{qPCR}$.

\subsection{Measurement of Isometric Tension of Isolated Rat Aortic} Rings. The aortic ring experiments were done according to the protocol already described in our laboratory [8, 10, 27]. On the day of the experiment and immediately before decapitation, all rats were anaesthetized with $75 \mathrm{mg} / \mathrm{kg}$ of ketamine (Ketanest S $25 \mathrm{mg} / \mathrm{ml}$, Pfizer) and $0.5 \mathrm{mg} / \mathrm{kg}$ of midazolam (Midazolam Torrex $5 \mathrm{mg} / \mathrm{ml}$, Torrex Chiesi Pharma). After decapitation, the descending thoracic aorta was dissected free from the connective tissue, placed in oxygenated modified Krebs-Henseleit solution, and cut into rings of about 3$4 \mathrm{~mm}$ in length. The solution consisting of (mM) $\mathrm{NaCl} 113$, $\mathrm{KCl} 4.7, \mathrm{MgSO}_{4} \cdot 6 \mathrm{H}_{2} \mathrm{O} 1.2, \mathrm{NaHCO}_{3} 22.0, \mathrm{CaCl}_{2} \cdot 2 \mathrm{H}_{2} \mathrm{O} 1.3$, $\mathrm{KH}_{2} \mathrm{PO}_{4} 1.2$, EDTA 0.026 , and glucose 11.1 was bubbled with a gas mixture of $95 \% \mathrm{O}_{2}$ and $5 \% \mathrm{CO}_{2}$ throughout the experiment, and was kept at a temperature of $37^{\circ} \mathrm{C}$. Two stainlesssteel hooks were inserted into the lumen of each aortic ring and mounted on a holder that was further placed in a $10 \mathrm{ml}$ organ bath, and the upper wire was connected to the transducer's arm via filament. The WPI Inc. system and PowerLab data acquisition and analysis software were used. Basal resting tension of $2.0 \mathrm{~g}$ was applied on each aortic ring and allowed to equilibrate for 60 minutes, replacing the KrebsHenseleit solution every $15 \mathrm{~min}$ with fresh solution and readjusting passive tension to $2.0 \mathrm{~g}$ as needed. Subsequently, the intactness of the endothelium was tested by precontracting the rings with $10^{-7} \mathrm{M}$ (final concentration) noradrenaline, letting to stabilize for $5 \mathrm{~min}$ and inducing relaxation with $10^{-5} \mathrm{M}$ acetylcholine. If the vessel ring failed to relax, it was not used for further studies. If the vessel ring relaxed, it was washed three times with fresh solution and allowed to equilibrate for $30 \mathrm{~min}$, with washing at $10 \mathrm{~min}$ intervals. After the rings were stabilized, maximal contraction was induced with $60 \mathrm{mM} \mathrm{KCl}+10^{-7} \mathrm{M}$ noradrenaline. When plateau was reached, the rings were washed three times with fresh solution and allowed to equilibrate for $30 \mathrm{~min}$, washing at 10 min intervals. After this phase, aortic ring responses to $\mathrm{ACh}$ or hypoxia were done. 
2.5. Protocols for Functional Vascular Studies in Aortic Rings. After triple washout and tension stabilization, the rings from all groups were subjected to one of the following experimental protocols. To assess baseline vasorelaxing potential, the intact rings from all groups were exposed to cumulative concentrations of $\mathrm{ACh}$ (acetylcholine chloride, SigmaAldrich, USA) $\left(10^{-9}-10^{-5} \mathrm{M}\right)$. To evaluate the role of $\mathrm{NO}$ and oxidative stress in the ACh-induced vasorelaxation, the intact rings from all groups were incubated for $10 \mathrm{~min}$ with (a) a NO synthase inhibitor, L-nitro-arginine methyl ester (L-NAME) (L-NAME hydrochloride, 1 g, Sigma, USA) $\left(3 \times 10^{-4} \mathrm{M}\right)$, to determine the role of NO in vascular relaxation and (b) a SOD mimetic, TEMPOL (4-hydroxy2,2,6,6-tetramethylpiperidine-1-oxyl, 25 g, Acros Organics, USA) $(100 \mu \mathrm{M})$, which was used before exposure to cumulative concentrations of $\mathrm{ACh}\left(10^{-9}-10^{-5} \mathrm{M}\right)$, to evaluate the role of superoxide.

After the equilibration and recovery period, rings were precontracted with $\mathrm{NE}\left(10^{-7} \mathrm{M}\right)$, and the gas mixture was switched from $95 \% \mathrm{O}_{2}$ and $5 \% \mathrm{CO}_{2}$ to $0 \% \mathrm{O}_{2}$ with $5 \% \mathrm{CO}_{2}$ for 20 minutes and then switched back to $95 \% \mathrm{O}_{2}$ with $5 \%$ $\mathrm{CO}_{2}$ for 5 minutes for reoxygenation. To evaluate the role of oxidative stress on the hypoxia-induced vasodilation, rings from all groups were incubated for 10 minutes with TEMPOL $(100 \mu \mathrm{M}$ final concentration) and hypoxia protocol was repeated. The relaxation was expressed as the percentage decrease of the NE-induced vasoconstriction.

The sensitivity of the smooth vascular muscle to NO was tested on intact rings from all groups. The aortic rings were exposed to cumulative doses of SNP (sodium nitroprusside dihydrate, $10^{-10}$ to $10^{-4} \mathrm{M}$ ), an endothelium-independent NO donor.

2.6. Serum Oxidative Stress Parameters' Analysis. Thiobarbituric acid-reactive substance (TBARS) assay and plasma antioxidant capacity (FRAP) assay were performed according to the established protocol in our laboratory [27, 28]. Arterial blood samples were collected from the femoral artery and centrifuged on $3500 \mathrm{rpm}$ for 10 minutes, and serum samples were stored at $-80^{\circ} \mathrm{C}$ until use. TBARS assay is based on the reaction of malondialdehyde (MDA), an end-product of lipid peroxidation, with TBARS. To correct for background absorption, the absorbance values at $572 \mathrm{~nm}$ were subtracted from those at $532 \mathrm{~nm}$, which represent the absorption maximum of the TBA:MDA adduct [29]. Absorbance was monitored by NanoPhotometer ${ }^{\circledR}$ P-Class P330-30 (Implen, Germany). Results were compared with a standard curve with MDA and expressed as $\mu \mathrm{M}$ MDA equivalents. The antioxidant capacity of plasma was measured by the ferric reducing antioxidant power (FRAP) assay. In this assay, antioxidants are evaluated as reductants of $\mathrm{Fe}^{3+}$ to $\mathrm{Fe}^{2+}$, which is chelated by TPTZ (2,4,6-tris(2-pyridyl)-s-triazine) to form a $\mathrm{Fe}^{2+}-\mathrm{TPTZ}$ complex absorbing at $593 \mathrm{~nm}$ [22]. Results were compared with a standard curve with Trolox (TE), a water-soluble analogue of vitamin E, and expressed as $\mu \mathrm{M}$ TE equivalents.

2.7. In Situ Evaluation of $\mathrm{O}_{2}^{-}$. Levels with Dihydroethidine (DHE) by Fluorescence Microscopy. Evaluation of $\mathrm{O}_{2}{ }^{-} \cdot$ levels was performed according to the protocol described by Zhu et al. [30]. Aortic ring samples were prepared as for functional vascular studies and cut into four rings of about $2-3 \mathrm{~mm}$ in length, precalibrated, and equilibrated for one hour at $37^{\circ} \mathrm{C}$ in Krebs-Henseleit solution and bubbled with a gas mixture of $95 \% \mathrm{O}_{2}$ and $5 \% \mathrm{CO}_{2}$. After the equilibration period, to assess the influence of TEMPOL on $\mathrm{O}_{2}{ }^{-} \cdot$ levels, 2 rings were incubated for 30 minutes in the same dosage as for functional studies (100 $\mu \mathrm{M}$ final concentration). To assess the $\mathrm{NOS}_{3}$ uncoupling effect, we performed an incubation with LNAME $\left(3 \times 10^{-4} \mathrm{M}\right)$ (only on aortic rings). After the incubation period, aortic rings were transferred to HEPES buffer (137 mM NaCl, $5.4 \mathrm{mM} \mathrm{KCl}, 4.2 \mathrm{mM} \mathrm{NaHCO}_{3}, 3 \mathrm{mM}$ $\mathrm{Na}_{2} \mathrm{HPO}_{4}, 0.4 \mathrm{mM} \mathrm{KH} \mathrm{PO}_{4}, 0.5 \mathrm{mM} \mathrm{MgCl} \cdot 6 \mathrm{H}_{2} \mathrm{O}, 0.8 \mathrm{mM}$ $\mathrm{MgSO}_{4} \cdot 7 \mathrm{H}_{2} \mathrm{O}, 10 \mathrm{mM}$ glucose, $20 \mathrm{mM}$ HEPES, and $1.2 \mathrm{mM}$ $\mathrm{CaCl}_{2} \cdot \mathrm{H}_{2} \mathrm{O}$ ) containing specific dye. The femoral artery about $3-4 \mathrm{~mm}$ in length was isolated and prepared in the same manner.

To assess the production of superoxide radicals, the aortic rings and femoral arteries were loaded with dihydroethidine (DHE, $20 \mu \mathrm{M}$ ) for $45 \mathrm{~min}$ in HEPES solution at $37^{\circ} \mathrm{C}$. DHE enters the cell, and ethidium binds to DNA in the cell, resulting in a strong red fluorescence. Measurements of DHE fluorescence were performed on a Zeiss Axioskop MOT2 microscope with an Olympus DP70 camera using a Zeiss filter set 15 with a $546 \mathrm{~nm}$ wavelength for excitation and a $590 \mathrm{~nm}$ wavelength for emission with a beam splitter at $580 \mathrm{~nm}$. Images were processed and analyzed by ImageJ software following the software developer's instructions (National Institutes of Health) [31, 32].

2.8. $m R N A$ Expression of Antioxidative Enzymes in Rat Aortas. Rat aorta samples were isolated, immediately frozen in liquid nitrogen, and stored at $-80^{\circ} \mathrm{C}$ until RNA isolation. Homogenization of samples and total RNA was extracted using TRI reagent (Life Technologies, USA) according to protocol by Chomczynski et al. (1987) [33], also established in our laboratory [28]. RNA purity and concentration were assessed by NanoPhotometer P-Class P330-30 (Implen, Germany). RNA was purified using deoxyribonuclease I kit (Sigma, USA), and cDNA was synthesized by the High Capacity cDNA kit with RNase Inhibitor (Applied Biosystems, USA). Quantitative real-time PCR was performed on the CFX96 system (Bio-Rad, USA) to assess the relative expression of eNOS, iNOS, superoxide dismutase isoforms 1,2 , and $3(\mathrm{Cu} / \mathrm{Zn} \mathrm{SOD}, \mathrm{Mn}$ SOD, EC SOD $\rightarrow$ SOD 1, 2, and 3), catalase, glutathione peroxidase 1 and 4 (GPx1 and GPx4), and nicotinamide adenine dinucleotide phosphate (NADPH) oxidase components (p47phox and gp91phox). Gene expression was normalized to the HPRT (hypoxanthine-guanine phosphoribosyltransferase) gene (HPRT expression in Table 1). Expression of these genes was determined using ABsolute qPCR SYBR Green Low ROX Mix (Thermo Scientific, Lithuania). All experiments were performed at the Dept. of Physiology and Immunology, Laboratory for Physiology of Circulation, and Laboratory for Molecular and Clinical Immunology and the Dept of Medical Biology and Genetics (fluorescence measurements), Faculty of Medicine, University of Osijek. 
TABLE 1: Relative expression of HPRT gene in aortic tissue.

\begin{tabular}{lcccc}
\hline & $\mathrm{CTRL}$ & $\mathrm{A}-\mathrm{HBO}_{2}$ & $24 \mathrm{H}-\mathrm{HBO}_{2}$ & $4 \mathrm{D}-\mathrm{HBO}_{2}$ \\
\hline & 305907953.65 & 582040046.02 & 206658013.40 & 17116739.21 \\
& 386556646.61 & 323880912.24 & 260830474.32 & 21126452.63 \\
\multirow{3}{*}{ HPRT } & 259559691.14 & 466690666.09 & 281799045.13 & 24126211.32 \\
& 319452834.56 & 148010504.98 & 221585966.06 & 24391652.31 \\
& 447773644.68 & 162037010.83 & 352353682.25 & 59118846.34 \\
\hline Average & 118147541.47 & 122675737.08 & 462065422.48 & 35533366.23 \\
\hline
\end{tabular}

TABLE 2: Measurements of body mass, arterial blood pressure, and mean arterial pressure.

\begin{tabular}{lcccc}
\hline & $\mathrm{CTRL}$ & $\mathrm{A}-\mathrm{HBO}_{2}$ & $24 \mathrm{H}-\mathrm{HBO}_{2}$ & $4 \mathrm{D}-\mathrm{HBO}_{2}$ \\
\hline Body mass (g) & $338.11 \pm 8.66$ & $336.33 \pm 8.79$ & $324.83 \pm 12.48$ & $320.71 \pm 12.35$ \\
Systolic blood pressure (mmHg) & $133.67 \pm 1.28$ & $98.33 \pm 1.41^{*}$ & $133.52 \pm 2.95$ & $136.47 \pm 2.65$ \\
Diastolic blood pressure (mmHg) & $93.65 \pm 1.81$ & $75.99 \pm 3.65^{*}$ & $96.12 \pm 4.50$ & $95.22 \pm 3.43$ \\
Mean arterial pressure (mmHg) & $106.99 \pm 1.49$ & $83.21 \pm 2.39^{*}$ & $108.59 \pm 3.93$ & $108.97 \pm 2.81$ \\
\hline
\end{tabular}

Results are shown as mean \pm SEM (standard error of mean); ${ }^{*} p<0.05$ compared to the control group.

2.9. Spectrophotometric Antioxidant Enzyme Activity Assay. Spectrophotometric antioxidant enzyme activities were measured according to the protocol described by Cosić et al. [28]. Fresh aorta samples were weighed and pulverized first with liquid nitrogen into which buffer is then added $(100 \mathrm{mM}$ phosphate buffer $+1 \mathrm{mM}$ EDTA, $\mathrm{pH} 7.0$ ) in proportion to the quantity-weighed tissue ( $1 \mathrm{ml}$ buffer per $100 \mathrm{mg}$ tissue) and then additionally homogenized with Ultra Turrax T10 homogenizer (1300 rpm; IKA, Königswinter, Germany). Tissue homogenates were then centrifuged at $20000 \mathrm{~g}$ for 15 minutes at $4^{\circ} \mathrm{C}$, and supernatants were stored at $-80^{\circ} \mathrm{C}$ until assayed.

Catalase (CAT) activity was measured according to protocol by Aebi [34], using $0.036 \%$ hydrogen peroxide $\left(\mathrm{H}_{2} \mathrm{O}_{2}\right)$ as a substrate in the reaction mixture with $50 \mathrm{mM}$ phosphate buffer $\mathrm{pH}$ 7.0. Changes in absorbance in the reaction mixture were measured at $240 \mathrm{~nm}$ during 2 minutes every 10 seconds after adding the sample. One unit of activity corresponds to the loss of $1 \mu \mathrm{mol}$ of $\mathrm{H}_{2} \mathrm{O}_{2}$ per minute.

Glutathione peroxidase (GPx) activity [35] was determined indirectly by measuring the rate of nicotinamide adenine dinucleotide phosphate (NADPH) oxidation to $\mathrm{NADP}^{+}$, accompanied by a decrease in absorbance at $340 \mathrm{~nm}$ during 5 minutes. In that assay, one unit of GPx activity catalyzes the oxidation by $\mathrm{H}_{2} \mathrm{O}_{2}$ of $1.0 \mu \mathrm{mol}$ of reduced glutathione to oxidized glutathione per minute at $\mathrm{pH} 7.0$ and $25^{\circ} \mathrm{C}$.

Total SOD activity in the supernatant is determined by the ability to inhibit the reduction of cytochrome $C$ by the superoxide anion by the addition of xanthine and xanthine oxidase. Activity was measured according to a modified method described by Flohé and Ötting [36]. Calibrations were performed with the use of a known amount of purified bovine SOD.
Measured activities of all investigated enzymes were expressed as units of the enzymes per milligram of protein (U/mg protein). Enzyme activity assay was performed using a Lambda $25 \mathrm{UV}$-Vis spectrophotometer equipped with UV WinLab 6.0 software package (PerkinElmer For the Better, Waltham, Massachusetts, USA). The concentration of proteins in samples $(\mathrm{mg} / \mathrm{ml})$ was determined following the protocol from the manufacturer of Bradford reagent at $595 \mathrm{~nm}$ (Bradford Reagent B6916, Sigma-Aldrich), using bovine serum albumin as a standard.

2.10. Statistical Analysis. All data are expressed as means \pm standard error of the means (SEM). $p<0.05$ was considered statistically significant. Data were analyzed using GraphPad Prism version 5.0 for Windows and SigmaPlot (version 11.2, Systat Software Inc., Chicago, USA). The normality of data distribution was assessed by the Kolmogorov-Smirnov normality test, and in the case of unequal distribution, nonparametric tests were applied. The data obtained from functional studies were analyzed by two-way ANOVA followed by the Bonferroni post hoc test for both pairwise comparisons and comparisons versus a control group. The analysis of oxidative stress and antioxidant capacity was performed using one-way ANOVA or Kruskal-Wallis test followed by the Holm-Sidak post hoc test, respectively. One-way ANOVA or the Kruskal-Wallis test was used for data analysis of real-time PCR where appropriate (Systat Software Inc., USA).

\section{Results}

3.1. General Information and Blood Pressure of Studied Groups. Body mass (g) of rats was not significantly different among examined groups. Data on the systolic, diastolic, 


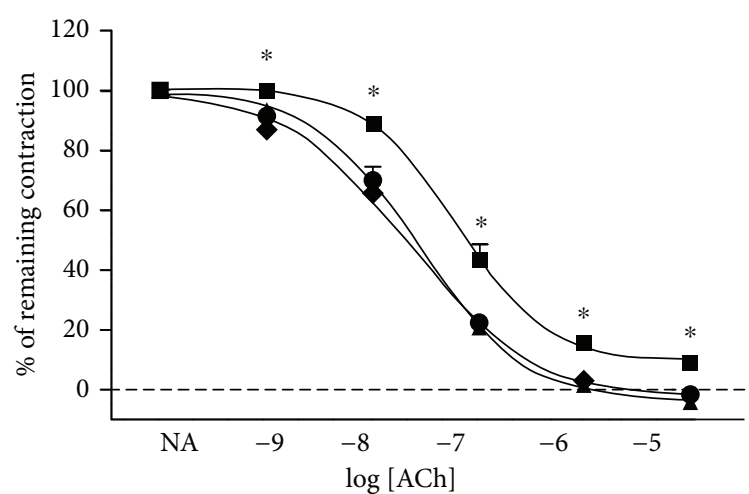

ACh: acetylcholine; NA; noradrenalin; $n$ : number of rats; $N$ : number of aortic rings Results are expressed as mean \pm SEM $* p<0.05 \mathrm{~A}-\mathrm{HBO}_{2}$ versus CTRL,

\begin{tabular}{lcc}
\hline CTRL $(n=5, N=20)$ & LogEC50 & EC50 (M) \\
A-HBO $(n=5, N=20)$ & -7.588 & $2.584 \mathrm{e}-08$ \\
$\mathbf{\Delta} 24 \mathrm{H}-\mathrm{HBO}_{2}(n=5, N=20)$ & $-7.215^{\dagger}$ & $6.093 \mathrm{e}-08$ \\
$4 \mathrm{H}-\mathrm{HBO}_{2}(n=5, N=20)$ & -7.566 & $2.717 \mathrm{e}-08$ \\
\hline
\end{tabular}

FIgURE 1: ACh-induced relaxation (AChIR) of isolated rat aorta rings in the CTRL, A- $\mathrm{HBO}_{2}, 24 \mathrm{H}-\mathrm{HBO}_{2}$, and $4 \mathrm{D}-\mathrm{HBO}_{2}$ groups. AChIR was significantly impaired in the $\mathrm{A}-\mathrm{HBO}_{2}$ group when compared to the other groups of rats with a $10^{-9}-10^{-5} \mathrm{M}$ ACh concentration. A- $\mathrm{HBO}_{2}$ rats exhibited lower sensitivity to $\mathrm{ACh}$ compared to other groups of rats (table). Half maximal effective concentration (EC50) presents concentration of ACh (M) which induces a response halfway between the baseline and maximum. LogEC50 values (shown in the corresponding tables) were compared by a one-way ANOVA test.

and mean arterial pressure before (CTRL) and immediately after $\mathrm{HBO}_{2}\left(\mathrm{~A}-\mathrm{HBO}_{2}\right), 24$ hours after $\mathrm{HBO}_{2}\left(24 \mathrm{H}-\mathrm{HBO}_{2}\right.$ group), and 4 days after $\mathrm{HBO}_{2}\left(4 \mathrm{D}-\mathrm{HBO}_{2}\right.$ group) are listed in Table 2. There was a significant decrease in systolic and diastolic blood pressure in the $\mathrm{A}-\mathrm{HBO}_{2}$ group compared to the control group. No changes in these variables were observed in other groups.

3.2. Acethylcholine-Induced Vasorelaxation (EndotheliumDependent) of Isolated Rat Aortic Rings. Figure 1 presents the results of isolated aortic ring vasorelaxation in response to ACh (AChIR) in all experimental groups of rats. AChIR was significantly reduced in the $\mathrm{A}-\mathrm{HBO}_{2}$ group compared to all other groups of animals. $\mathrm{A}-\mathrm{HBO}_{2}$ rats also exhibited lower sensitivity to ACh compared to other groups of rats (presented by $\operatorname{logEC} 50$ in the tables with each graph).

The role of NO and oxidative stress in AChIR is presented in Figure 2. In all experimental groups of rats, ACh relaxation was mediated mainly by $\mathrm{NO}$ and was significantly inhibited by the addition of eNOS inhibitor L-NAME. NO contributed less to AChIR in the $24 \mathrm{H}-\mathrm{HBO}_{2}$ group (at $\mathrm{ACh}$ $10^{-6}$ and $10^{-5} \mathrm{M}$ ) and in the $4 \mathrm{D}-\mathrm{HBO}_{2}$ group (at ACh $10^{-7}$, $10^{-6}$, and $10^{-5} \mathrm{M}$ ) compared to the untreated controls
(Figure 3(a)). Still, contribution of NO to AChIR was less in the $4 \mathrm{D}-\mathrm{HBO}_{2}$ group than in the $\mathrm{A}-\mathrm{HBO}_{2}$ group of rats (Figure 3(a)). There were no differences in sensitivity to $\mathrm{ACh}$ in the presence of L-NAME among groups (logEC50 values in the tables within Figure 3(a)).

However, in all tested groups, within-group tests revealed that in the presence of L-NAME, the sensitivity to ACh was significantly lower compared to the basic response to $\mathrm{ACh}$ and response to $\mathrm{ACh}$ in the presence of TEMPOL in the corresponding group $(\operatorname{logEC} 50$ values in the tables within Figures 2(a)-2(d)).

In the $\mathrm{A}-\mathrm{HBO}_{2}$ group, in vitro superoxide scavenger TEMPOL restored the relaxation response to ACh similar to the basal values of other experimental groups (Figure 2(b)). TEMPOL did not affect AChIR in the CTRL (Figure 2(a)), $24 \mathrm{H}$ $\mathrm{HBO}_{2}$ (Figure $2(\mathrm{c})$ ), and $4 \mathrm{D}-\mathrm{HBO}_{2}$ groups (Figure 2(d)). In the $4 \mathrm{D}-\mathrm{HBO}_{2}$ group, AChIR in the presence of TEMPOL was lower compared to $24 \mathrm{H}-\mathrm{HBO}_{2}$ (at ACh $10^{-8}$ and $10^{-7} \mathrm{M}$ ) (Figure $3(\mathrm{~b})$ ). Sensitivity to ACh after TEMPOL incubation was also significantly decreased in $4 \mathrm{D}-\mathrm{HBO}_{2}$ compared to the other groups.

3.3. Hypoxia-Induced Vasorelaxation (HIR) of Isolated Rat Aortic Rings. A- $\mathrm{HBO}_{2}$ groups exhibited significantly decreased vasorelaxation in response to hypoxia compared to all other groups of rats. The $24 \mathrm{H}-\mathrm{HBO}_{2}$ and $4 \mathrm{D}-\mathrm{HBO}_{2}$ groups exhibited significantly enhanced vasorelaxation in response to hypoxia compared to the CTRL and A- $\mathrm{HBO}_{2}$ groups of rats (Figure 4).

After incubation of aortic rings with TEMPOL, vasorelaxation in response to hypoxia in the $\mathrm{A}-\mathrm{HBO}_{2}$ group was restored to the levels similar to the control group. There was no effect of TEMPOL on HIR in the CTRL group. However, in the presence of TEMPOL, HIR in the $24 \mathrm{H}-$ $\mathrm{HBO}_{2}$ group was significantly increased compared to baseline (Figure 5).

3.4. Sodium Nitroprusside-Induced Vasorelaxation (Endothelium-Independent) of Isolated Rat Aortic Rings. Aortic ring relaxation in response to sodium nitroprusside (SNP), an endothelium-independent NO donor, was similar between all tested groups (Figure 6). A- $\mathrm{HBO}_{2}$ and $24 \mathrm{H}$ $\mathrm{HBO}_{2}$ groups exhibited higher sensitivity to SNP compared to CTRL, and the $24 \mathrm{H}-\mathrm{HBO}_{2}$ group exhibited higher sensitivity to $\mathrm{SNP}$ compared to $4 \mathrm{D}-\mathrm{HBO}_{2}(\operatorname{logEC} 50$ values in the table within the graphs in Figure 6).

3.5. Oxidative Stress, Antioxidative Capacity, and Superoxide Production. Serum TBARS, the measure of lipid oxidation products, was significantly increased in the $\mathrm{A}-\mathrm{HBO}_{2}$ group compared to the CTRL, $24 \mathrm{H}-\mathrm{HBO}_{2}$, and $4 \mathrm{D}-\mathrm{HBO}_{2}$ groups. There was no significant difference in antioxidant capacity (FRAP values) among all tested groups (Table 3).

Aortic and femoral artery superoxide production was significantly increased in the $\mathrm{A}-\mathrm{HBO}_{2}$ group compared to all other groups. TEMPOL in vitro significantly decreased superoxide production in the $\mathrm{A}-\mathrm{HBO}_{2}$ group similar to basal values of other groups (Figures $7(\mathrm{a}), 7(\mathrm{~b}), 8(\mathrm{a})$, and 8(b)). L-NAME in vitro significantly decreased superoxide 


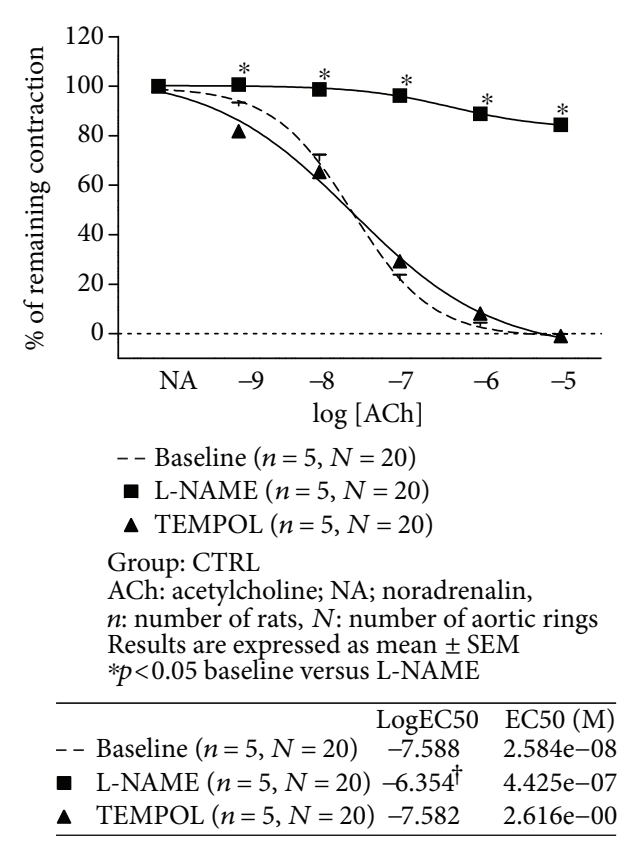

(a)

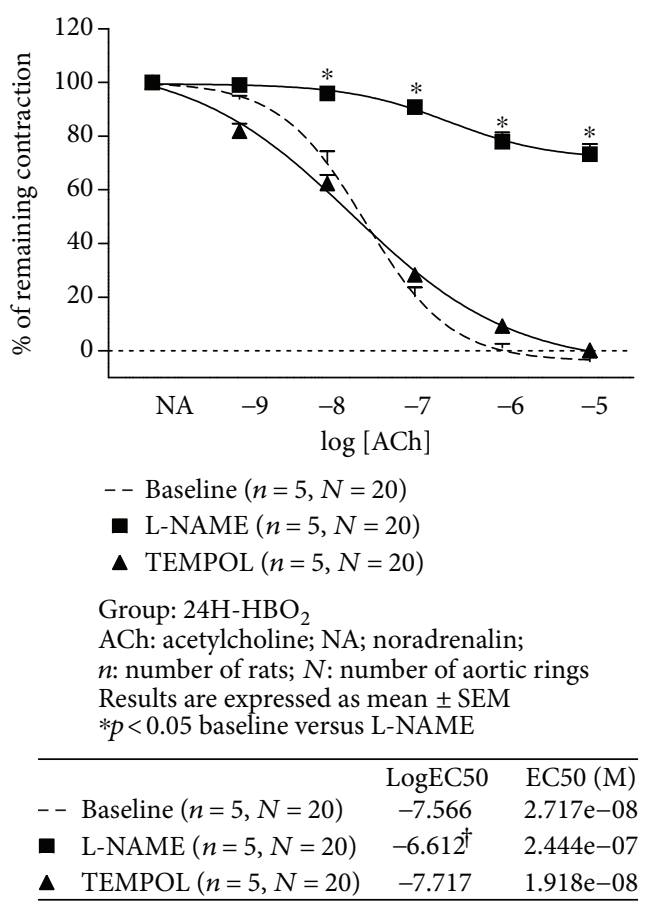

(c)

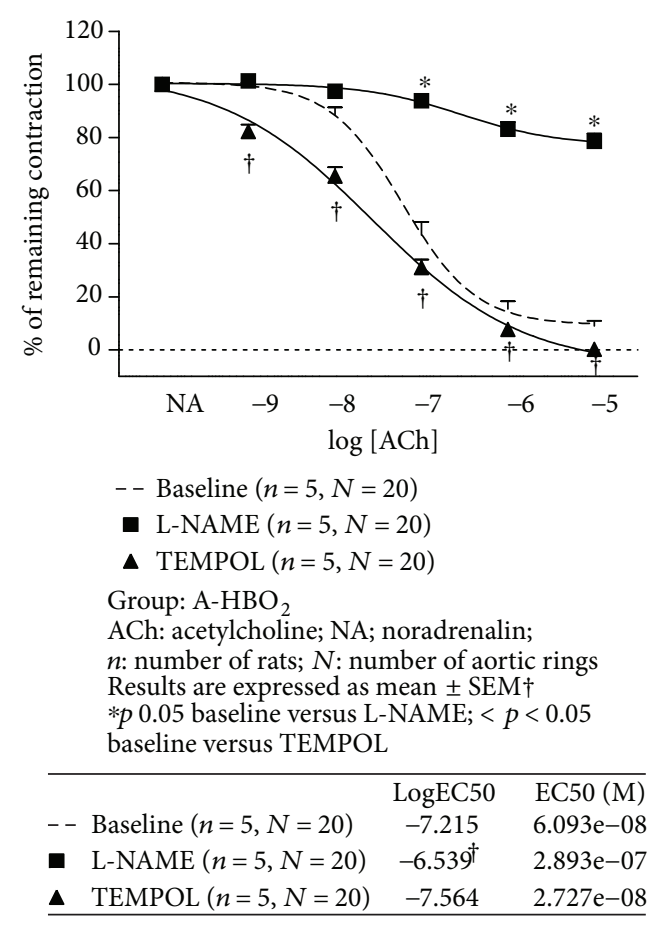

(b)

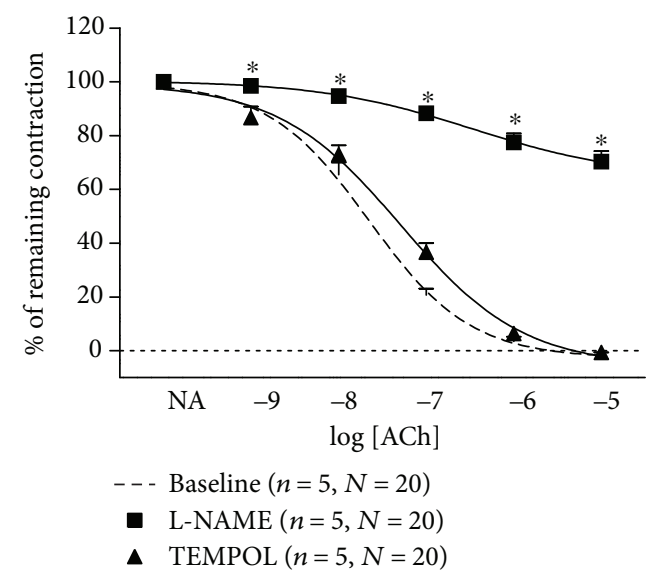

Group: 4D-HBO

ACh: acetylcholine; NA; noradrenalin;

$n$ : number of rats, $N$ : number of aortic rings

Results are expressed as mean \pm SEM

$* p<0.05$ baseline versus L-NAME

\begin{tabular}{ccc}
\hline & LogEC50 & EC50 (M) \\
- - Baseline $(n=5, N=20)$ & -7.652 & $2.226 \mathrm{e}-08$ \\
- L-NAME $(n=5, N=20)$ & $-6.469^{\dagger}$ & $3.395 \mathrm{e}-07$ \\
\ TEMPOL $(n=5, N=20)$ & -7.291 & $5.120 \mathrm{e}-08$ \\
\hline
\end{tabular}

(d)

FIGURE 2: Mechanisms of AChIR response of isolated rat aorta rings in the CTRL (a), A- $\mathrm{HBO}_{2}(\mathrm{~b}), 24 \mathrm{H}-\mathrm{HBO}_{2}$ (c), and $4 \mathrm{D}-\mathrm{HBO}_{2}$ (d) groups of rats. Used concentrations: ACh $10^{-9}$ to $10^{-5} \mathrm{M}$, L-NAME $3 \times 10^{-4} \mathrm{M}$, and TEMPOL $100 \mu \mathrm{M}$. Half maximal effective concentration (EC50) presents the concentration of ACh $(\mathrm{M})$ which induces a response halfway between the baseline and maximum. The presence of L-NAME significantly reduced AChIR of isolated rat aortic rings in all experimental groups. TEMPOL administration significantly increased the AChIR response in the A- $\mathrm{HBO}_{2}$ group of rats, while it did not induce any significant change in the AChIR of isolated rat aortic rings in other groups. Data were compared by two-way ANOVA and Bonferroni post hoc tests. Tables within figures present sensitivity of aortic rings to $\mathrm{ACh}$ in the CTRL (a), A- $\mathrm{HBO}_{2}$ (b), $24 \mathrm{H}-\mathrm{HBO}_{2}$ (c), and $4 \mathrm{D}-\mathrm{HBO}_{2}$ (d) groups of rats. Sensitivity to ACh in the presence of L-NAME was significantly decreased compared to the basic response or response to ACh in the presence of TEMPOL in all experimental groups of rats. LogEC50 values were compared by one-way ANOVA followed by a Holm-Sidak pairwise multiple comparison. 


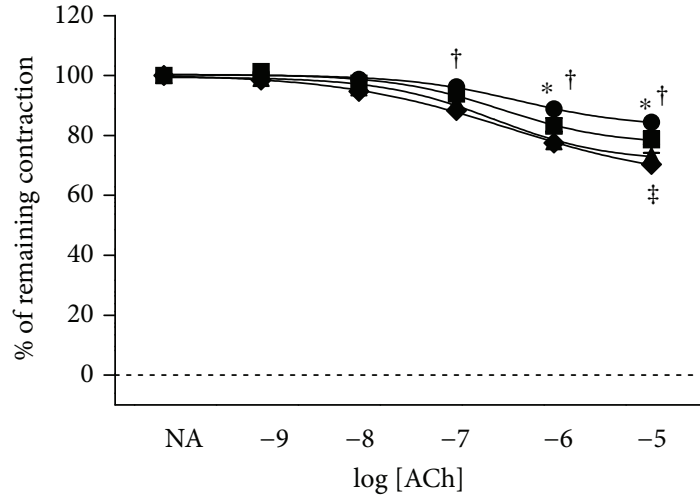

L-NAME

ACh: acetylcholine; NA; noradrenalin;

$n$ : number of rats; $N$ : number of aortic rings

Results are expressed as mean \pm SEM

${ }^{*} p<0.05 \mathrm{CTRL}$ versus $24 \mathrm{H}-\mathrm{HBO}_{2}$;

${ }^{\dagger} p<0.05 \mathrm{CTRL}$ versus $4 \mathrm{D}-\mathrm{HBO}_{2}$;

${ }^{\ddagger} p<0.054 \mathrm{D}-\mathrm{HBO}_{2}$ versus $\mathrm{A}-\mathrm{HBO}_{2}$

\begin{tabular}{lcc}
\hline & $\operatorname{LogEC} 50$ & EC50 (M) \\
- CTRL $(n=5, N=20)$ & -6.354 & $4.425 \mathrm{e}-07$ \\
A-HBO $(n=5, N=20)$ & -6.539 & $2.893 \mathrm{e}-07$ \\
\ $24 \mathrm{H}-\mathrm{HBO}_{2}(n=5, N=20)$ & -6.612 & $2.444 \mathrm{e}-07$ \\
$-4 \mathrm{H}-\mathrm{HBO}_{2}(n=5, N=20)$ & -6.469 & $3.395 \mathrm{e}-07$ \\
\hline
\end{tabular}

(a)

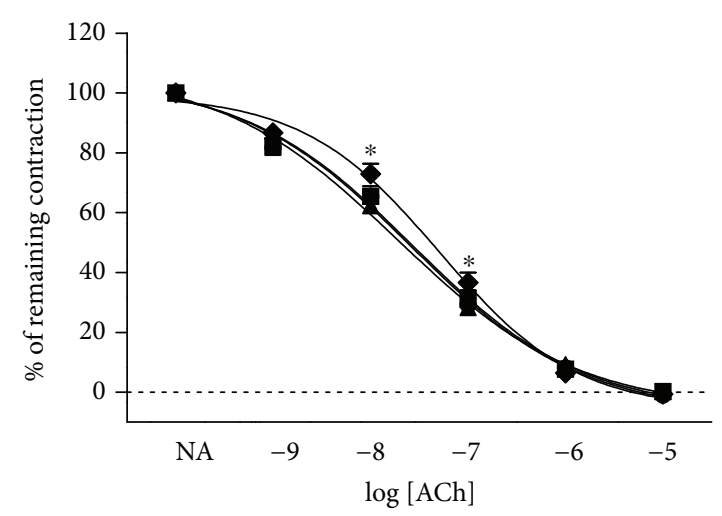

TEMPOL

ACh: acetylcholine; NA; noradrenalin; $n$ : number of rats; $N$ : number of aortic rings Results are expressed as mean \pm SEM ${ }^{*} p<0.0524 \mathrm{H}-\mathrm{HBO}_{2}$ versus $4 \mathrm{D}-\mathrm{HBO}_{2}$

\begin{tabular}{lcl}
\hline & $\operatorname{LogEC} 50$ & EC50 (M) \\
- CTRL $(n=5, N=20)$ & -7.582 & $2.616 \mathrm{e}-08$ \\
- A-HBO $(n=5, N=20)$ & -7.564 & $2.727 \mathrm{e}-08$ \\
$\triangle 24 \mathrm{H}-\mathrm{HBO}_{2}(n=5, N=20)$ & -7.717 & $1.918 \mathrm{e}-08$ \\
$\bullet 4 \mathrm{H}-\mathrm{HBO}_{2}(n=5, N=20)$ & $-7.291 \S$ & $5.120 \mathrm{e}-08$ \\
\hline
\end{tabular}

(b)

FIGURE 3: Relaxation to acetylcholine in the presence of eNOS inhibitor L-NAME (a) and superoxide scavenger TEMPOL (b) in the CTRL, A- $-\mathrm{HBO}_{2}, 24 \mathrm{H}-\mathrm{HBO}_{2}$, and $4 \mathrm{D}-\mathrm{HBO}_{2}$ groups of rats. The presence of L-NAME inhibited AChIR more prominently in CTRL compared to $24 \mathrm{H}-\mathrm{HBO}_{2}$ and $4 \mathrm{D}-\mathrm{HBO}_{2}$ groups, and in $\mathrm{A}-\mathrm{HBO}_{2}$ that in the $4 \mathrm{D}-\mathrm{HBO}_{2}$ group of rats. AChIR in the presence of TEMPOL was lower in $4 \mathrm{D}-\mathrm{HBO}_{2}$ than in the $24 \mathrm{H}-\mathrm{HBO}_{2}$ group for ACh concentrations $10^{-8}$ and $10^{-7} \mathrm{M}$. Data were compared by two-way ANOVA and Bonferroni post hoc tests. Tables within figures present sensitivity of aortic rings to ACh in the presence of L-NAME (a) and TEMPOL (b) in the CTRL, A- $\mathrm{HBO}_{2}, 24 \mathrm{H}-\mathrm{HBO}_{2}$, and $4 \mathrm{D}-\mathrm{HBO}_{2}$ groups of rats. Sensitivity to ACh in the presence of L-NAME did not differ among experimental groups of rats. Sensitivity to ACh in the presence of TEMPOL was significantly decreased in the $4 \mathrm{D}-\mathrm{HBO}_{2}$ group compared to the other groups of rats. LogEC50 values were compared by one-way ANOVA followed by a Holm-Sidak pairwise multiple comparison.

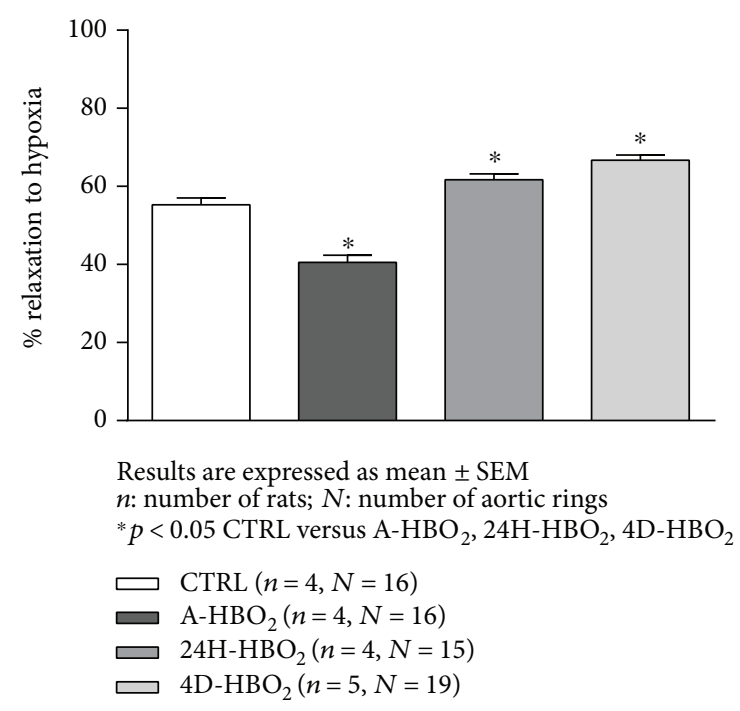

FIgURE 4: Hypoxia-induced relaxation (HIR) response of isolated rat aorta rings in the CTRL, A- $\mathrm{HBO}_{2}, 24 \mathrm{H}-\mathrm{HBO}_{2}$, and $4 \mathrm{D}-\mathrm{HBO}_{2}$ groups. HIR was significantly lower in $\mathrm{A}-\mathrm{HBO}_{2}$ compared to all other groups of rats. The $24-\mathrm{HBO}_{2}$ and $4 \mathrm{D}-\mathrm{HBO}_{2}$ groups exhibited significantly increased HIR compared to CTRL and $\mathrm{A}-\mathrm{HBO}_{2}$ groups of rats. production in the $\mathrm{A}-\mathrm{HBO}_{2}$ group in aortic rings and showed no effect on other groups (Figure 9).

3.6. mRNA Expression of Oxidative and Antioxidative Genes in the Rat Aortic Tissue. Aortic SOD1 and SOD3 gene mRNA expression was significantly higher in the $4 \mathrm{D}-\mathrm{HBO}_{2}$ group compared to all other groups. Aortic mRNA expression of SOD2 was not significantly different among groups. Expression of catalase, GPx1, GPx4, and NADPH oxidase components was significantly increased in the $4 \mathrm{D}-\mathrm{HBO}_{2}$ group compared to the control group, while expression of GPx1 and NADPH oxidase components mRNA was also significantly increased in the $4 \mathrm{D}-\mathrm{HBO}_{2}$ group compared to A$\mathrm{HBO}_{2}$ and $24 \mathrm{H}-\mathrm{HBO}_{2}$. Catalase and $\mathrm{GPx} 4 \mathrm{mRNA}$ expression was significantly increased in the $24 \mathrm{H}-\mathrm{HBO}_{2}$ group compared to the control group (Table 4).

The relative aortic mRNA expression of iNOS was significantly decreased in the $\mathrm{A}-\mathrm{HBO}_{2}$ and $24 \mathrm{H}-\mathrm{HBO}_{2}$ groups compared to the control group, while expression of eNOS was not significantly different among groups (Table 4). The relative expression of mRNA of studied genes was normalized to the HPRT (hypoxanthine-guanine phosphoribosyltransferase) gene mRNA expression (HPRT expression in Table 1). 


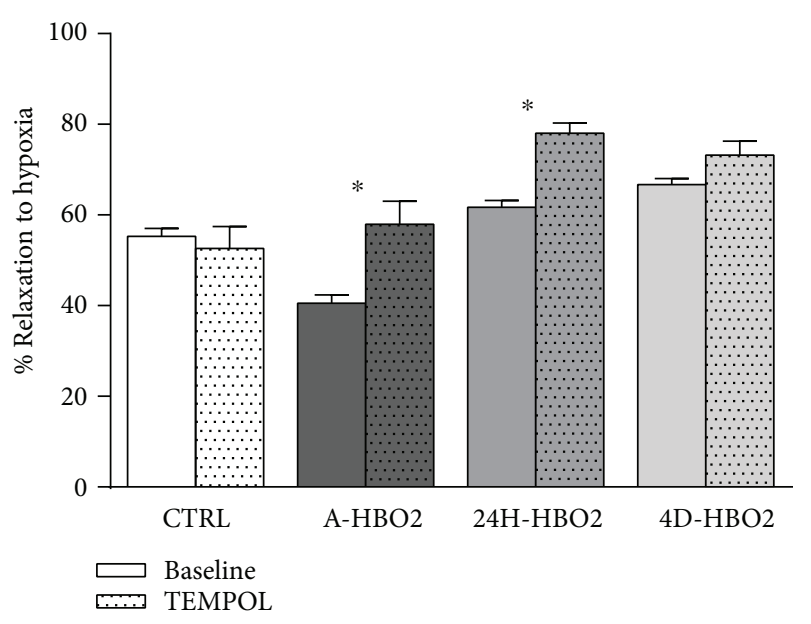

CTRL baseline $n=4, N=16$, TEMPOL $n=4, N=16$; A- $\mathrm{HBO}_{2}$ baseline $n=4, N=16$, TEMPOL $n=4, N=16$; $24 \mathrm{H}-\mathrm{HBO}_{2}$ baseline $n=4, N=15$, TEMPOL $n=5, N=20$; $4 \mathrm{D}-\mathrm{HBO}_{2}$ baseline $n=5, N=19$, TEMPOL $n=5, N=19$.

Results are expressed as mean \pm SEM $n$ : number of rats; $N$ : number of aortic rings $* p<0.05$ baseline versus TEMPOL for $\mathrm{A}-\mathrm{HBO}_{2}$ and $24 \mathrm{H}-\mathrm{HBO}_{2}$ groups

Figure 5: Relaxation to hypoxia in the presence of superoxide scavenger TEMPOL in the CTRL, A- $\mathrm{HBO}_{2}, 24 \mathrm{H}-\mathrm{HBO}_{2}$, and $4 \mathrm{D}-\mathrm{HBO}_{2}$ groups of rats. TEMPOL administration significantly increased HIR compared to baseline measurement in the $\mathrm{A}-\mathrm{HBO}_{2}$ and $24 \mathrm{H}-\mathrm{HBO}_{2}$ groups of rats.

3.7. Antioxidant Enzyme Activities. Activity of catalase in aortic tissue is significantly increased in the $4 \mathrm{D}-\mathrm{HBO}_{2}$ group compared to the CTRL and $\mathrm{A}-\mathrm{HBO}_{2}$ groups, and activity of $\mathrm{GpX}$ is increased in the $4 \mathrm{D}-\mathrm{HBO}_{2}$ group compared to all other groups. There are no differences in SOD activity among tested groups (Table 5).

\section{Discussion}

The main findings of the present study are as follows: acute single exposure to $\mathrm{HBO}_{2}$ impairs vasorelaxation in response to ACh and hypoxia. These impaired responses are restored by superoxide scavenging. Superoxide production was increased in acute hyperbaric treatment and not affected by intermittent hyperbaric treatment. In addition, antioxidative enzyme expression, as well as iNOS expression, was increased in intermittent hyperbaric treatment. These results suggest that impaired vasorelaxation to $\mathrm{ACh}$ and hypoxia in acute $\mathrm{HBO}_{2}$ may be influenced by increased vascular oxidative stress, that is, superoxide formation. Increased oxidative stress is supported by findings of increased serum lipid peroxidation products and increased aortic superoxide production in the acute single exposure group $\left(\mathrm{A}-\mathrm{HBO}_{2}\right)$. Hink et al. [14] also reported that acute $\mathrm{HBO}_{2}$ exposure has decreased ACh relaxation, but they did not show a scavenging effect on superoxide and hydrogen peroxide by PEGSOD and PEG-catalase and therefore could not explain such

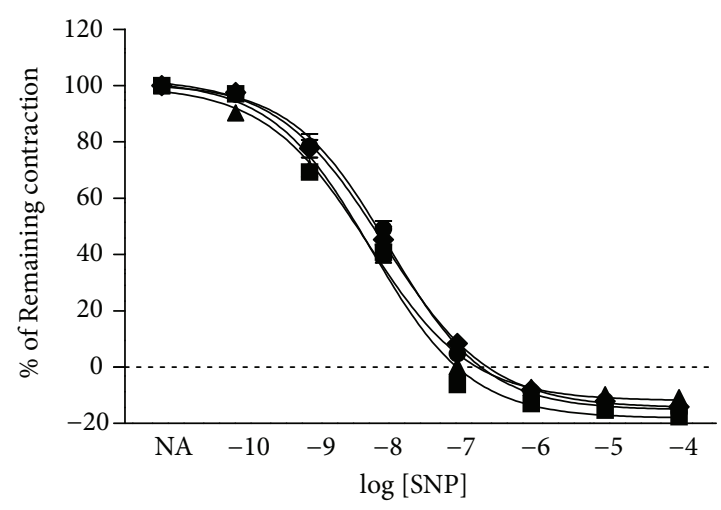

SNP: sodium nitroprusside; NA: noradrenalin; $n$ : number of rats; $N$ : number of aortic rings Results are expressed as mean \pm SEM

\begin{tabular}{lcc}
\hline CTRL $(n=3, N=12)$ & LogEC50 & EC50 (M) \\
A-HBO $(n=4, N=16)$ & $-6.928^{\dagger}$ & $1.181 \mathrm{e}-07$ \\
$\mathbf{\Delta} 24 \mathrm{H}-\mathrm{HBO}_{2}(n=4, N=16)$ & -7.165 & $6.840 \mathrm{e}-08$ \\
$4 \mathrm{H}-\mathrm{HBO}_{2}(n=4, N=15)$ & $-6.997^{\ddagger}$ & $6.129 \mathrm{e}-08$ \\
\hline
\end{tabular}

FIGURE 6: SNP-induced relaxation (SNPIR) of isolated rat aorta rings in the CTRL, A- $\mathrm{HBO}_{2}, 24 \mathrm{H}-\mathrm{HBO}_{2}$, and $4 \mathrm{D}-\mathrm{HBO}_{2}$ groups. There was no difference in SNPIR among experimental groups of rats. Data were compared by two-way ANOVA and Bonferroni post hoc tests. The CTRL group exhibited lower sensitivity to SNP compared to the $\mathrm{A}-\mathrm{HBO}_{2}$ and $24 \mathrm{H}-\mathrm{HBO}_{2}$ groups of rats $\left({ }^{\dagger} p<0.05\right)$; the $4 \mathrm{D}-\mathrm{HBO}_{2}$ group exhibited lower sensitivity to SNP compared to the $24 \mathrm{H}-\mathrm{HBO}_{2}$ group of rats $\left({ }^{\ddagger} p<0.05\right)$ (table). Half maximal effective concentration (EC50) presents concentration of SNP (M) which induces a response halfway between the baseline and maximum. LogEC50 values (shown in corresponding tables) were compared by one-way ANOVA test.

decrease. They performed in vitro experiments simulating $\mathrm{HBO}_{2}$ conditions. It is therefore possible that an increase in $\mathrm{PO}_{2}$ in buffer shortens the lifetime and, hence, decreases the bioavailability of NO which then leads to a decrease in Achinduced relaxation. In contrast, we exposed living animals in a hyperbaric chamber and isolated the vessels after decompression and then observed the decrease in ACh-induced relaxation. Luo et al. [37] showed an almost equally scavenging effect of PEG-SOD and TEMPOL, and therefore, improvement of vascular relaxation in our experiment can be connected to superoxide scavenging. The present study is the first one to directly assess the production of superoxide and expression of antioxidative enzymes in different $\mathrm{HBO}_{2}$ protocols and to relate it to vascular reactivity.

In the present study, $\mathrm{NOS}_{3}$ uncoupling could be a source of increased superoxide production immediately after $\mathrm{HBO}_{2}$ treatment. Active $\mathrm{NOS}_{3}$, which is the dominant isoform in the endothelium $[38,39]$, is a homodimer that generates NO and L-citrulline from L-arginine. When exposed to oxidative stress or deprived of its reducing cofactor tetrahydrobiopterin (BH4) or substrate L-arginine, $\mathrm{NOS}_{3}$ uncouples to the monomeric form which generates $\mathrm{O}_{2}{ }^{-} \cdot$ rather than $\mathrm{NO}$ [40-42]. Uncoupled $\mathrm{NOS}_{3}$ is thought to be a prominent source of 
TABLE 3: The effects of hyperbaric oxygen on the level of oxidative stress (TBARS) and antioxidative capacity (FRAP) in serum samples.

\begin{tabular}{lcccrr}
\hline & $N$ & $\mathrm{CTRL}$ & $\mathrm{A}-\mathrm{HBO}_{2}$ & $24 \mathrm{H}-\mathrm{HBO}_{2}$ & $4 \mathrm{D}-\mathrm{HBO}_{2}$ \\
\hline TBARS $(\mu \mathrm{mol} \mathrm{l}$ & -1 \\
FRAP $\left(\mathrm{mmol}{ }^{-1}\right.$ TROLOX) & 8 & $0.66 \pm 0.02$ & $0.86 \pm 0.04^{*}$ & $0.64 \pm 0.02$ & $0.62 \pm 0.02$ \\
\hline
\end{tabular}

Results are shown as mean \pm SEM (standard error of mean); ${ }^{*} p<0.05$ compared to the control group. TBARS: thiobarbituric acid-reactive substances; FRAP: ferric reducing ability of plasma, plasma antioxidant capacity.

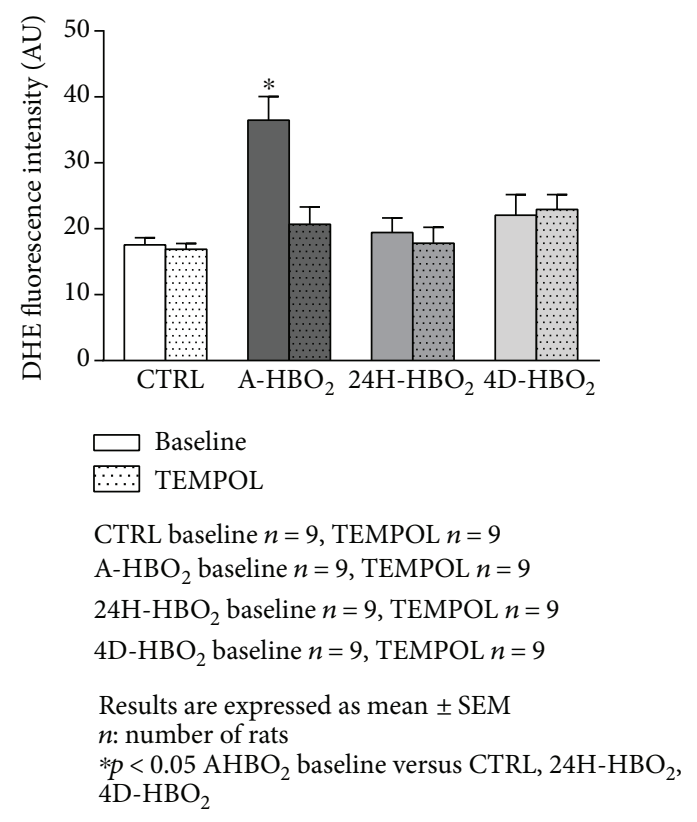

(a)

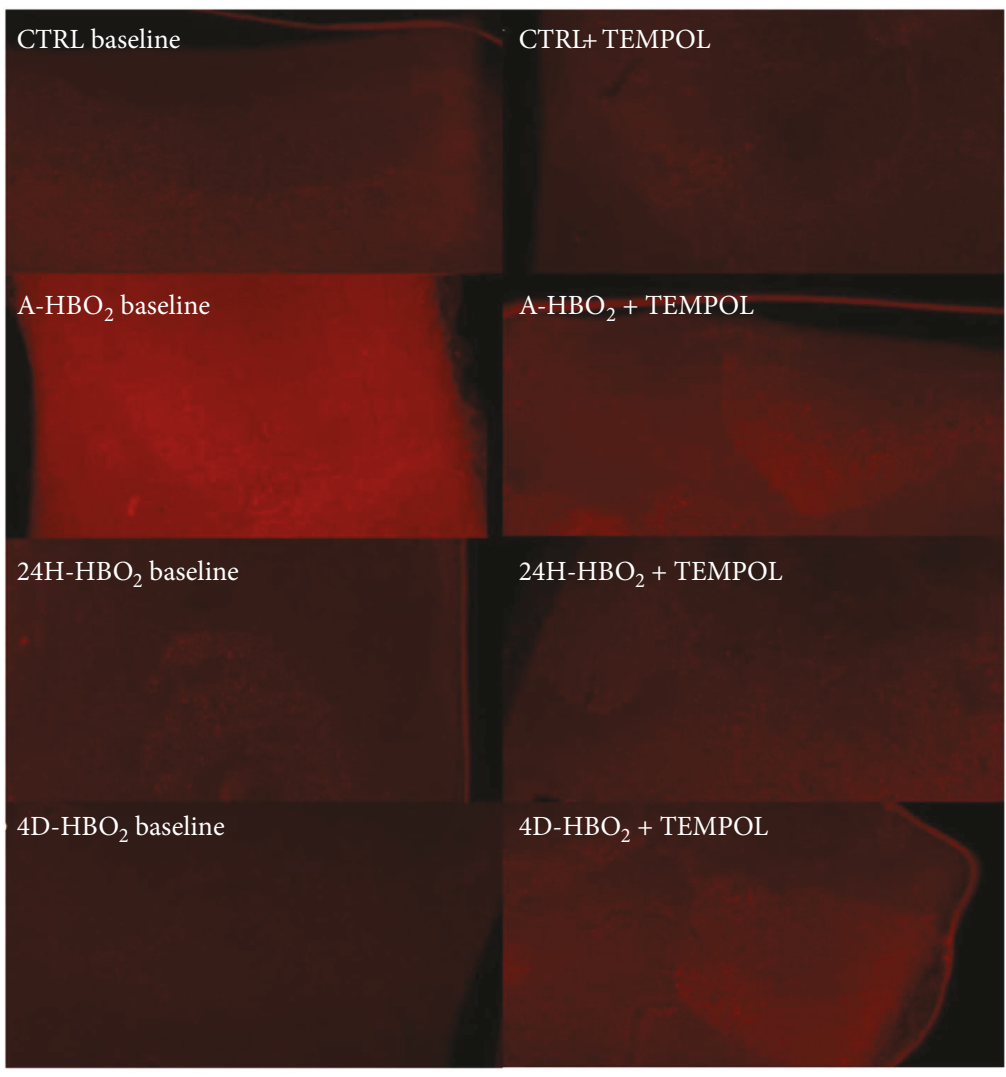

(b)

FIgURE 7: (a) DHE superoxide fluorescence intensity measurement in rat aorta. The increase in superoxide levels in the aortas of rats exposed to hyperbaric oxygen was prevented by incubation with TEMPOL. Data are shown as means \pm SEM of DHE fluorescence intensity units. *Significant increase in superoxide levels compared with control value before any treatment ( $p<0.05 ; n=9$ rats). (b) In situ fluorescence of superoxide after dying of aortic rings with DHE color in all tested groups before and after incubation with TEMPOL. The color intensity is proportional to the amount of superoxide. The images were made on the Zeiss Axioskop MOT2 microscope, using the Olympus DP70 camera with the Zeiss filter set 15 (546 nm wavelength for excitation and $590 \mathrm{~nm}$ for emission with a beam splitter at $580 \mathrm{~nm}$ ).

endothelial ROS in various disorders connected to endothelial dysfunction, such as hypertension [43]. However, in long-term exposure, the main source of superoxide seems to be NADPH. We observed an increased mRNA expression of NADPH oxidase components in the $4 \mathrm{D}-\mathrm{HBO}_{2}$ group, and our experiments with L-NAME have not demonstrated a decrease in superoxide production in that group (Figure 9).

Endothelial oxygen-derived free radicals can inactivate $\mathrm{NO}$ formation $[44,45]$; therefore, the effect of acute $\mathrm{HBO}_{2}$ exposure on ACh-induced relaxation, found to be reversible, is consistent with the study by Ay et al., who showed that the oxidative effect of $\mathrm{HBO}_{2}$ persists only for $1 \mathrm{~h}$ [46]. The present study also demonstrates that the effects of a hyperbaric oxygenation in producing increased oxidative stress and impaired endothelium-dependent vasorelaxation are extremely rapid, but transient, because significant changes were detected after only one exposure to $\mathrm{HBO}_{2}$, but have been lost $24 \mathrm{~h}$ after exposure (Figures 1 and 4, Table 3). Results of the present study suggest reduced contribution of $\mathrm{NO}$ to $\mathrm{ACh}$-induced relaxation in $\mathrm{HBO}_{2}$-exposed animals, despite increased sensitivity of the vascular smooth muscle to NO, which seems to be in proportion to the duration of $\mathrm{HBO}_{2}$ treatment. Namely, $\mathrm{HBO}_{2}$ exposure can provoke adoptive mechanisms and alleviate oxidative stress even in healthy animals (Figure 3(a)). In concordance to these findings are recent studies from our laboratory presented by 


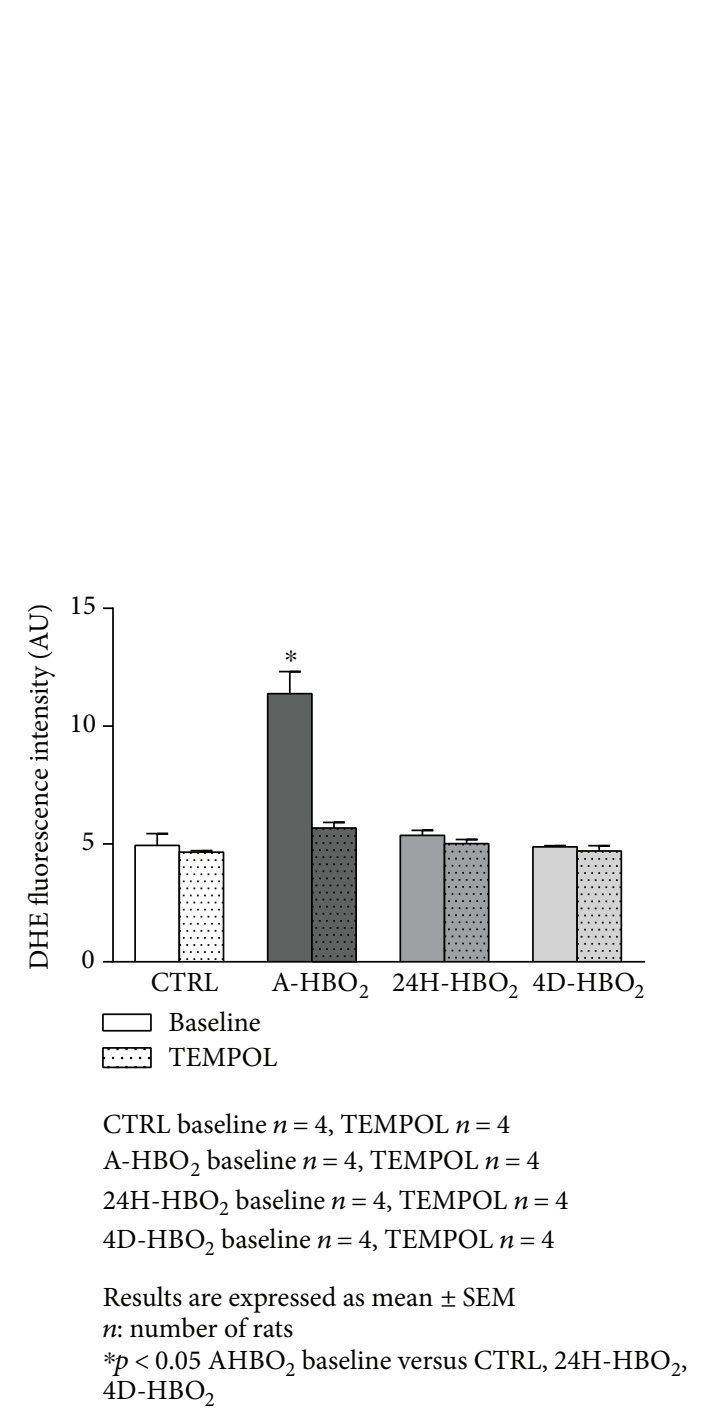

(a)

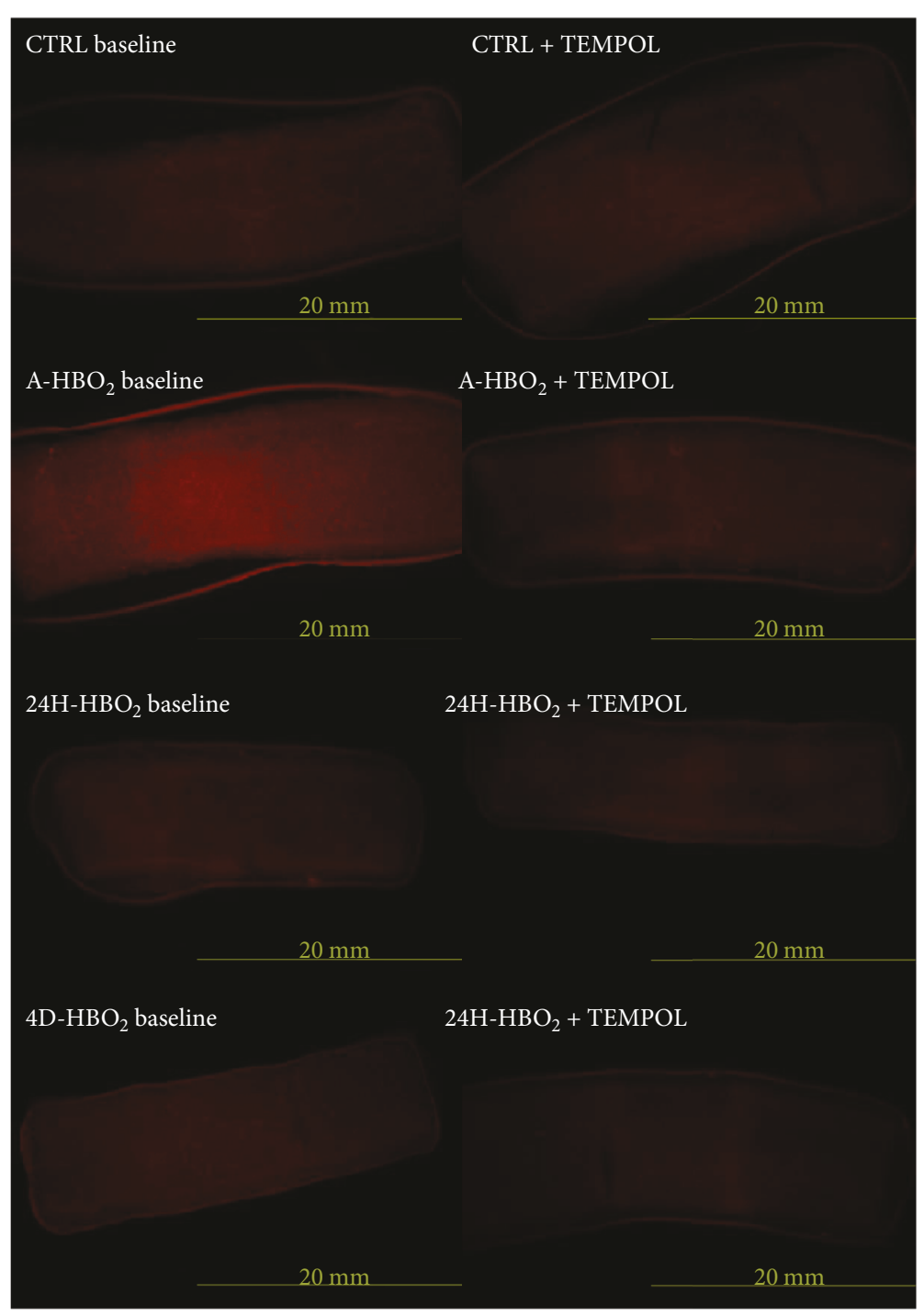

(b)

FIGURE 8: (a) DHE superoxide fluorescence intensity measurement in the rat femoral artery. The increase in superoxide levels in the artery of rats exposed to a single session of hyperbaric oxygen was prevented by incubation with TEMPOL. Data are shown as means \pm SEM of DHE fluorescence intensity units. * Significant increase in superoxide levels compared with control value before any treatment ( $p<0.05 ; n=4$ rats). (b) In situ fluorescence of superoxide after dying of the femoral artery with DHE color in all tested groups before and after incubation with TEMPOL. The color intensity is proportional to the amount of superoxide. The images were made on the Zeiss Axioskop MOT2 microscope, using the Olympus DP70 camera with the Zeiss filter set 15 (546 nm wavelength for excitation and $590 \mathrm{~nm}$ for emission with a beam splitter at $580 \mathrm{~nm})$.

Kibel et al. [8] and Unfirer et al. [10] which showed the presence of an alternative pathway(s) of endothelium-dependent vasorelaxation to acetylcholine and ANG (1-7) in diabetic animals exposed to 4 days of hyperbaric oxygen, most probably involving enhanced production or sensitivity to EETs (epoxyeicosatrienoic acid). Studies in animal models show that there is an interaction between the enzymes that produce the vasoactive metabolites (NOS, COX-1, COX-2, and CYP450) and oxygen-free radicals (ROS) [47]. The ROS may be by-products of impaired activation of these enzymes together with the activation of $\mathrm{NAD}(\mathrm{P}) \mathrm{H}$ oxidase, while ROS may act on COX enzymes in a manner that changes its direction in the production of vasoconstrictor metabolites. In addition, ROS may act by reducing the bioavailability of NO [47].

Previous studies of hyperbaric oxygen exposure showed increased oxidative stress after long-term exposure [13, 2426]. This is in contrast to our previous [10] and present study, mainly by the duration and manner of exposure to $\mathrm{HBO}_{2}$, as well as the time of tissue harvesting. In addition, none of the mentioned studies examined the effect of $\mathrm{HBO}_{2}$ on antioxidant enzyme expression [13, 24-26]. Previously, we hypothesized $[19,48]$ that the time between two exposures can be observed as pseudohypoxia which is important 


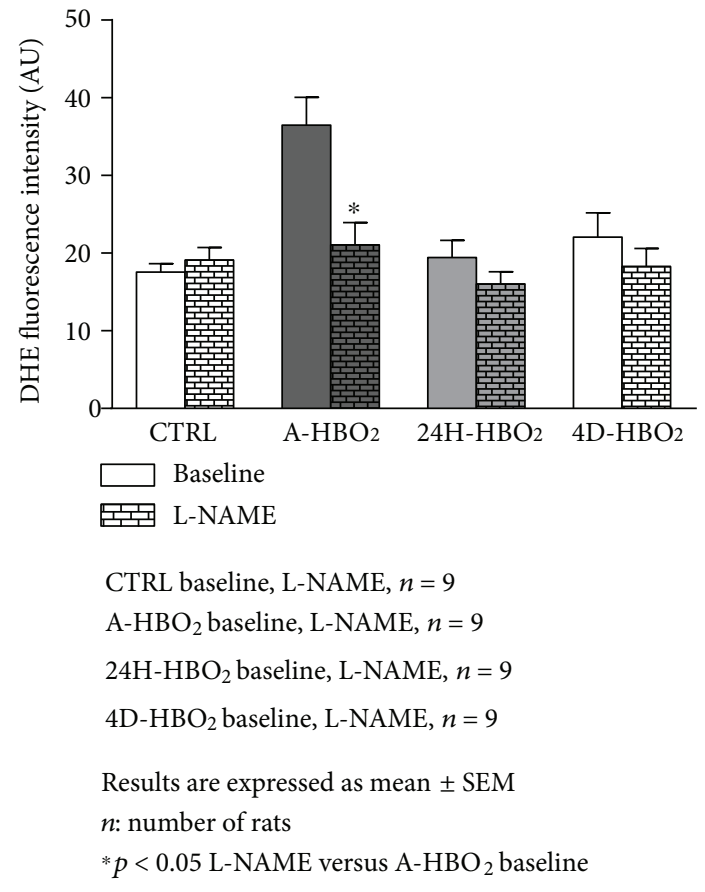

FIGURE 9: DHE superoxide fluorescence intensity measurement in the rat aorta before and after incubation with L-NAME. The superoxide levels in the aortas of rats exposed to a single session of hyperbaric oxygen was decreased by incubation with L-NAME compared to baseline. Data are shown as means \pm SEM of DHE fluorescence intensity units. * Significant decrease in superoxide levels after L-NAME incubation compared with baseline value $(p<0.05 ; n=9$ rats $)$.

for upregulating antioxidative enzymes (as demonstrated in Table 4), as well as other enzymes important for maintaining vascular relaxation mechanisms $[19,48]$. In the present study, increased expression and activity of antioxidative enzymes in the $4 \mathrm{D}-\mathrm{HBO}_{2}$ group have been observed (Tables 4 and 5). The main source of superoxide in the $4 \mathrm{D}-\mathrm{HBO}_{2}$ group seems to be NADPH oxidase. However, at the same time, there was a significant upregulation of SOD1 and SOD3 in the $4 \mathrm{D}-\mathrm{HBO}_{2}$ group and a lower superoxide production observed in direct fluorescence measurements, speaking in favor of intermittent hyperoxygenation treatment as beneficial in increasing vascular antioxidative mechanisms. Similarly, some former studies reported that when $\mathrm{HBO}_{2}$ was administered for more than a single exposure, an adaptive mechanism which protects against further oxidative damage was activated $[49,50]$. Thus, preconditioning with $\mathrm{HBO}_{2}$ treatment may be used to preserve several organs or tissues from following oxidative injuries [51, 52]. These adaptive and preconditioning actions triggered by $\mathrm{HBO}_{2}$ treatments may also be responsible for changes in the underlying mechanisms of vascular reactivity in the present and previous studies $[8,10,53,54]$. Since $\mathrm{HBO}_{2}$ is an important therapy with life-saving properties in various conditions and its efficacy generally depends on repeated exposures for several days [55], it is of particular importance to define its molecular interactions when administered in a repetitive manner. The present results suggest that intermittent exposure to $\mathrm{HBO}_{2}$ leads to a more effective scavenging of ROS and to the activation of protective responses including antioxidant gene expression and increased antioxidative enzyme activities.

Even though unchanged activity of total SOD enzymes was surprising (Table 1), it is in concordance with the findings of Mamo et al., who related mRNA expression and activity of enzyme discordance with increased nitration of SOD [56]. It is known that hyperoxia increases ROS production, such as peroxynitrite. Reactive nitrogen species can inhibit activity of multiple antioxidants, including SOD [57]. Since SOD scavenges superoxide and prevents its reaction with $\mathrm{NO}$, extracellular superoxide production in excess of the SOD antioxidant capacity promotes formation of both ROS and RNS [58]. This can occur due to loss of SOD activity or to increase in NO production [56, 59]. Another possibility involves enhanced generation of oxidants such as $\mathrm{H}_{2} \mathrm{O}_{2}$ under hyperoxic conditions. $\mathrm{H}_{2} \mathrm{O}_{2}$ has been shown to inactivate SOD through modification of the active site of the enzyme [60], and, for example, estimated brain $\mathrm{H}_{2} \mathrm{O}_{2}$ concentrations during $\mathrm{HBO}_{2}$ are as much as 2-7 times normoxic values [61]. Levels of $\mathrm{H}_{2} \mathrm{O}_{2}$ were not measured in this study, but increased mRNA expression and activity of CAT and GpX can support this explanation. Taken together, our results of increased mRNA expressions and no changes in activity of the SOD enzymes suggest efficient oxidative stress management in the $4 \mathrm{D}-\mathrm{HBO}_{2}$ group who exhibited improved vasorelaxation.

Further studies concentrated on transcription factors, and their target genes known to be triggered and activated with $\mathrm{HBO}_{2}$ may help to elucidate the exact pathways and molecular interactions which occur during or after repeated $\mathrm{HBO}_{2}$ administrations [62].

\section{Study Limitations}

This study was done only on male rats to avoid any influence of sex hormones or sex itself. Previously, we did an aortic ring reactivity assay on female diabetic rats (data not published) where we observed a protective role of sex hormones [63]. Also it is known that oestrogenes can have antioxidant potential [64] and may improve redox balance and thus influence endothelium-dependent relaxation [65]; therefore, we choose to perform experiments on male rats only.

\section{Conclusion}

The results in this study showed impaired endothelialdependent vasorelaxation in acute $\mathrm{HBO}_{2}$ which was transient and reversible and was caused by increased superoxide production and overall increased oxidative stress. On the other hand, intermittent $\mathrm{HBO}_{2}$ exposure exhibited a beneficial effect on vascular relaxation and preserved it, due to increased vascular antioxidant capacity. The present study is the first one to directly assess the production of superoxide and expression of antioxidative enzymes in different $\mathrm{HBO}_{2}$ protocols and to relate it to the vascular reactivity. 


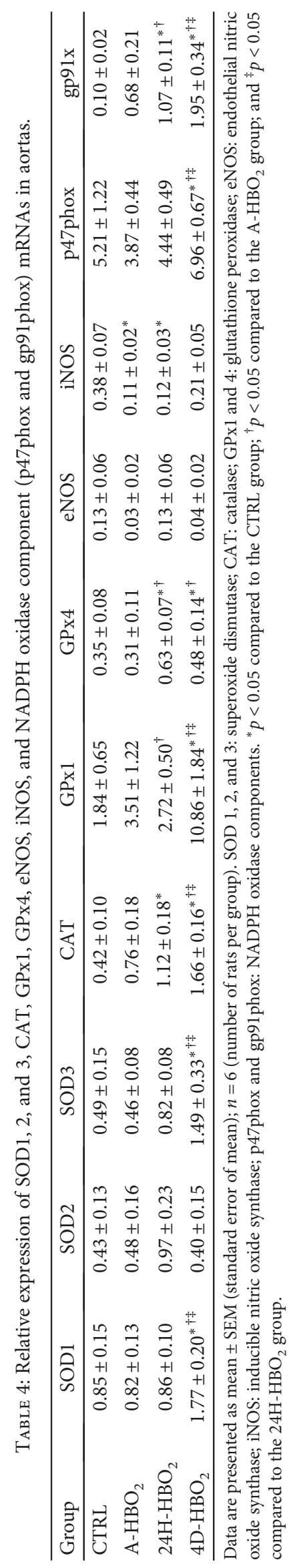


Table 5: Antioxidant enzyme activities.

\begin{tabular}{lcccc}
\hline Experimental group & $N$ & CAT $(\mathrm{U} / \mathrm{mg} \mathrm{P})$ & GpX $(\mathrm{U} / \mathrm{mg}$ P) & SOD (U/mg P) \\
\hline CTRL & 4 & $43.82 \pm 7.34$ & $0.16 \pm 0.01$ & $19.31 \pm 0.34$ \\
$\mathrm{~A}-\mathrm{HBO}_{2}$ & 4 & $49.75 \pm 2.58$ & $0.14 \pm 0.02$ & $18.75 \pm 0.32$ \\
$24 \mathrm{H}-\mathrm{HBO}_{2}$ & 4 & $57.80 \pm 9.48$ & $0.18 \pm 0.02$ & $18.89 \pm 1.06$ \\
$4 \mathrm{D}-\mathrm{HBO}_{2}$ & 4 & $69.67 \pm 4.54^{* \dagger}$ & $0.48 \pm 0.10^{* \dagger}$ & $17.40 \pm 0.25$ \\
\hline
\end{tabular}

Data are presented as mean \pm SEM. ${ }^{*} p<0.05$ compared to CTRL; ${ }^{\dagger} p<0.05$ compared to A- $\mathrm{HBO}_{2}$; and ${ }^{\ddagger} p<0.05$ compared to $24 \mathrm{H}-\mathrm{HBO}{ }_{2}$. P: protein; $\mathrm{CAT}$ : catalase; GpX: glutathione peroxidase; SOD: superoxide dismutase.

\section{Conflicts of Interest}

The authors declare that there is no conflict of interest regarding the publication of this article.

\section{Acknowledgments}

This study was supported by a grant from the Ministry of Science, Education and Sports of the Republic of Croatia (no. 219-2160133-2034) and the Faculty of Medicine Osijek VIF-2016-MEFOS-19 grant (Principal Investigator Ines Drenjancevic). Sanja Novak, PhD, helped in the animal handling and preparation. Aleksandar Kibel, $\mathrm{MD}, \mathrm{PhD}$, advised and helped with blood pressure measurements.

\section{References}

[1] I. Takac, S. Kvolik, D. Divkovic, J. Kalajdzic-Candrlic, S. Puseljic, and S. Izakovic, "Conservative surgical management of necrotic tissues following meningococcal sepsis: case report of a child treated with hyperbaric oxygen," Undersea and Hyperbaric Medicine Journal, vol. 37, no. 2, pp. 95-99, 2010.

[2] K. Korhonen, J. Klossner, M. Hirn, and J. Niinikoski, "Management of clostridial gas gangrene and the role of hyperbaric oxygen," Annales Chirurgiae et Gynaecologiae, vol. 88, no. 2, pp. 139-142, 1999.

[3] E. A. Dotsenko, N. V. Nikulina, D. P. Salivonchik, O. G. Lappo, A. I. Gritsuk, and A. S. Bastron, "Low doses of hyperbaric oxygenation effectively decrease the size of necrotic zone in rats with experimental myocardial infarction," Bulletin of Experimental Biology and Medicine, vol. 158, no. 6, pp. 732-734, 2015.

[4] Q. Hu, A. Manaenko, H. Bian et al., "Hyperbaric oxygen reduces infarction volume and hemorrhagic transformation through ATP/NAD ${ }^{+} /$Sirtl pathway in hyperglycemic middle cerebral artery occlusion rats," in Stroke, vol. 48, no. 6, pp. 1655-1664, 2017.

[5] L. D. Zhang, L. Ma, L. Zhang et al., "Hyperbaric oxygen and ginkgo biloba extract ameliorate cognitive and memory impairment via nuclear factor kappa-B pathway in rat model of Alzheimer's disease," Chinese Medical Journal, vol. 128, no. 22, pp. 3088-3093, 2015.

[6] X. Pan, C. Chen, J. Huang, H. Wei, and Q. Fan, "Neuroprotective effect of combined therapy with hyperbaric oxygen and madopar on 6-hydroxydopamine-induced Parkinson's disease in rats," Neuroscience Letters, vol. 600, pp. 220-225, 2015.
[7] X. Chen, Y. Li, W. Chen, Z. Nong, J. Huang, and C. Chen, "Protective effect of hyperbaric oxygen on cognitive impairment induced by D-galactose in mice," Neurochemical Research, vol. 41, no. 11, pp. 3032-3041, 2016.

[8] A. Kibel, S. Novak, A. Cosic, Z. Mihaljevic, J. R. Falck, and I. Drenjancevic, "Hyperbaric oxygenation modulates vascular reactivity to angiotensin-(1-7) in diabetic rats: potential role of epoxyeicosatrienoic acids," Diabetes and Vascular Disease, vol. 12 , no. 1 , pp. 33-45, 2015.

[9] D. Mathieu, A. Marroni, and J. Kot, "Tenth European Consensus Conference on Hyperbaric Medicine: recommendations for accepted and non-accepted clinical indications and practice of hyperbaric oxygen treatment," Diving and Hyperbaric Medicine, vol. 47, no. 1, pp. 24-32, 2017.

[10] S. Unfirer, M. Mihalj, S. Novak et al., "Hyperbaric oxygenation affects the mechanisms of acetylcholine-induced relaxation in diabetic rats," Undersea and Hyperbaric Medicine Journal, vol. 43, no. 7, pp. 787-803, 2016.

[11] C. A. Godman, R. Joshi, C. Giardina, G. Perdrizet, and L. E. Hightower, "Hyperbaric oxygen treatment induces antioxidant gene expression," Annals of the New York Academy of Sciences, vol. 1197, no. 1, pp. 178-183, 2010.

[12] S. R. Thom, "Oxidative stress is fundamental to hyperbaric oxygen therapy," Journal of Applied Physiology, vol. 106, no. 3, pp. 988-995, 2009.

[13] K. Simsek, H. Ay, T. Topal et al., "Long-term exposure to repetitive hyperbaric oxygen results in cumulative oxidative stress in rat lung tissue," Inhalation Toxicology, vol. 23, no. 3, pp. 166-172, 2011.

[14] J. Hink, S. R. Thom, U. Simonsen, I. Rubin, and E. Jansen, "Vascular reactivity and endothelial NOS activity in rat thoracic aorta during and after hyperbaric oxygen exposure," American Journal of Physiology-Heart and Circulatory Physiology, vol. 291, no. 4, pp. H1988-H1998, 2006.

[15] S. R. Thom, V. Bhopale, D. Fisher, Y. Manevich, P. L. Huang, and D. G. Buerk, "Stimulation of nitric oxide synthase in cerebral cortex due to elevated partial pressures of oxygen: an oxidative stress response," Journal of Neurobiology, vol. 51, no. 2, pp. 85-100, 2002.

[16] D. A. Rossignol, L. W. Rossignol, S. J. James, S. Melnyk, and E. Mumper, "The effects of hyperbaric oxygen therapy on oxidative stress, inflammation, and symptoms in children with autism: an open-label pilot study," BMC Pediatrics, vol. 7, no. 1, p. 36, 2007.

[17] C. Li-Fan, T. Yu-Feng, L. Cheng-Hsien, H. Lian-Yu, N. KoChi, and L. Mao-Tsun, "Repetitive hyperbaric oxygen therapy provides better effects on brain inflammation and oxidative damage in rats with focal cerebral ischemia," Journal of the Formosan Medical Association, vol. 113, pp. 620-628, 2014. 
[18] S. Oter, A. Korkmaz, T. Topal et al., "Correlation between hyperbaric oxygen exposure pressures and oxidative parameters in rat lung, brain, and erythrocytes," Clinical Biochemistry, vol. 38, no. 8, pp. 706-711, 2005.

[19] I. Drenjancevic, A. Kibel, D. Kibel, V. Seric, and A. Cosic, "Blood pressure, acid-base and blood gas status and indicators of oxidative stress in healthy male rats exposed to acute hyperbaric oxygenation," Undersea and Hyperbaric Medicine Journal, vol. 40, no. 4, pp. 319-328, 2013.

[20] I. Drenjancevic and A. Kibel, "Restoring vascular function with hyperbaric oxygen treatment: recovery mechanisms," Journal of Vascular Research, vol. 51, no. 1, pp. 1-13, 2014.

[21] C. Dennog, P. Radermacher, Y. A. Barnett, and G. Speit, "Antioxidant status in humans after exposure to hyperbaric oxygen," Mutation Research, vol. 428, no. 1-2, pp. 83-89, 1999.

[22] I. F. F. Benzie and J. J. Strain, "The ferric reducing ability of plasma (FRAP) as a measure of "antioxidant power": the FRAP assay," Analytical Biochemistry, vol. 239, no. 1, pp. 7076, 1996.

[23] G. W. Winston, F. Regoli, A. J. Dugas Jr, J. H. Fong, and K. A. Blanchard, "A rapid gas chromatographic assay for determining oxyradical scavenging capacity of antioxidants and biological fluids," Free Radical Biology and Medicine, vol. 24, no. 3, pp. 480-493, 1998.

[24] S. Benedetti, A. Lamorgese, M. Piersantelli, S. Pagliarani, F. Benvenuti, and F. Canestrari, "Oxidative stress and antioxidant status in patients undergoing prolonged exposure to hyperbaric oxygen," Clinical Biochemistry, vol. 37, no. 4, pp. 312-317, 2004.

[25] N. Bader, A. Bosy-Westphal, A. Koch, and M. J. Mueller, "Influence of vitamin $\mathrm{C}$ and $\mathrm{E}$ supplementation on oxidative stress induced by hyperbaric oxygen in healthy men," Annals of Nutrition \& Metabolism, vol. 50, no. 3, pp. 173176, 2006.

[26] N. Bader, A. Bosy-Westphal, A. Koch et al., "Effect of hyperbaric oxygen and vitamin $\mathrm{C}$ and $\mathrm{E}$ supplementation on biomarkers of oxidative stress in healthy men," British Journal of Nutrition, vol. 98, no. 4, pp. 826-833, 2007.

[27] A. Stupin, A. Ćosić, S. Novak et al., "Reduced dietary selenium impairs vascular function by increasing oxidative stress in Sprague-Dawley rat aortas," International Journal of Environmental Research and Public Health, vol. 14, no. 6, p. 591, 2017.

[28] A. Ćosić, I. Jukić, A. Stupin et al., “Attenuated flow-induced dilatation of middle cerebral arteries is related to increased vascular oxidative stress in rats on a short-term high salt diet," Journal of Physiology, vol. 594, no. 17, pp. 4917-4931, 2016.

[29] K. D. Oakes and G. J. Van Der Kraak, "Utility of the TBARS assay in detecting oxidative stress in white sucker (Catostomus Commersoni) populations exposed to pulp mill effluent," Aquatic Toxicology, vol. 63, no. 4, pp. 447-463, 2003.

[30] J. Zhu, T. Mori, T. Huang, and J. H. Lombard, "Effect of highsalt diet on NO release and superoxide production in rat aorta," American Journal of Physiology-Heart and Circulatory Physiology, vol. 286, no. 2, pp. H575-H583, 2004.

[31] T. J. Collins, "ImageJ for microscopy," BioTechniques, vol. 43, no. S1, pp. S25-S30, 2007.

[32] V. Girish and A. Vijayalakshmi, "Affordable image analysis using NIH Image/ImageJ," Indian Journal of Cancer, vol. 41, no. 1, p. $47,2004$.
[33] P. Chomczynski and N. Sacchi, "Single-step method of RNA isolation by acid guanidinium thiocyanate-phenol-chloroform extraction," Analytical Biochemistry, vol. 162, no. 1, pp. 156159, 1987.

[34] H. Aebi, "[13] Catalase in vitro," Methods in Enzymology, vol. 105, pp. 121-126, 1984.

[35] A. Wendel, "Glutathione peroxidase," in Enzymatic basis of detoxication, W. B. Jakoby, Ed., pp. 333-353, Academic Press, New York, NY, USA, 1980.

[36] L. Flohé and F. Ötting, "[10] Superoxide dismutase assays," Methods in Enzymology, vol. 105, pp. 93-104, 1984.

[37] Z. Luo, Y. Chen, S. Chen et al., "Comparison of inhibitors of superoxide generation in vascular smooth muscle cells," British Journal of Pharmacology, vol. 157, no. 6, pp. 935943, 2009.

[38] P. B. Massion and J. L. Balligand, "Modulation of cardiac contraction, relaxation and rate by the endothelial nitric oxide synthase (eNOS): lessons from genetically modified mice," The Journal of Physiology, vol. 546, no. 1, pp. 63-75, 2003.

[39] H. C. Champion, D. Georgakopoulos, E. Takimoto, T. Isoda, Y. Wang, and D. A. Kass, "Modulation of in vivo cardiac function by myocyte-specific nitric oxide synthase-3," Circulation Research, vol. 94, no. 5, pp. 657-663, 2004.

[40] N. Kuzkaya, N. Weissmann, D. G. Harrison, and S. Dikalov, "Interactions of peroxynitrite, tetrahydrobiopterin, ascorbic acid, and thiols: implications for uncoupling endothelial nitric-oxide synthase," Journal of Biological Chemistry, vol. 278, no. 25, pp. 22546-22554, 2003.

[41] Y. Xia, V. L. Dawson, T. M. Dawson, S. H. Snyder, and J. L. Zweier, "Nitric oxide synthase generates superoxide and nitric oxide in arginine-depleted cells leading to peroxynitritemediated cellular injury," Proceedings of the National Academy of Sciences of the United States of America, vol. 93, no. 13, pp. 6770-6774, 1996.

[42] G. M. Rosen, P. Tsai, J. Weaver et al., "The role of tetrahydrobiopterin in the regulation of neuronal nitric-oxide synthase-generated superoxide," Journal of Biological Chemistry, vol. 277, no. 43, pp. 40275-40280, 2002.

[43] U. Landmesser, S. Dikalov, S. R. Price et al., "Oxidation of tetrahydrobiopterin leads to uncoupling of endothelial cell nitric oxide synthase in hypertension," Journal of Clinical Investigation, vol. 111, no. 8, pp. 1201-1209, 2003.

[44] H. Cai and D. G. Harrison, "Endothelial dysfunction in cardiovascular diseases: the role of oxidant stress," Circulation Research, vol. 87, no. 10, pp. 840-844, 2000.

[45] D. G. Harrison, "Endothelial function and oxidant stress," Clinical Cardiology, vol. 20, 11 Supplement 2, pp. II-11-II17, 1997.

[46] H. Ay, T. Topal, M. Ozler et al., "Persistence of hyperbaric oxygen-induced oxidative effects after exposure in rat brain cortex tissue," Life Sciences, vol. 80, no. 22, pp. 2025-2029, 2007.

[47] J. Zhu, I. Drenjancevic-Peric, S. McEwen et al., "Role of superoxide and angiotensin II suppression in salt-induced changes in endothelial $\mathrm{Ca}^{2+}$ signaling and NO production in rat aorta," American Journal of Physiology-Heart and Circulatory Physiology, vol. 291, no. 2, pp. H929-H938, 2006.

[48] S. Unfirer, A. Kibel, and I. Drenjancevic-Peric, "The effect of hyperbaric oxygen therapy on blood vessel function in diabetes mellitus," Medical Hypotheses, vol. 71, no. 5, pp. 776-780, 2008. 
[49] A. Rothfuss, C. Dennog, and G. Speit, "Adaptive protection against the induction of oxidative DNA damage after hyperbaric oxygen treatment," Carcinogenesis, vol. 19, no. 11, pp. 1913-1917, 1998.

[50] A. Rothfuss and G. Speit, "Investigations on the mechanism of hyperbaric oxygen (HBO)-induced adaptive protection against oxidative stress," Mutation Research/Fundamental and Molecular Mechanisms of Mutagenesis, vol. 508, no. 1-2, pp. 157-165, 2002.

[51] V. Jadhav, R. P. Ostrowski, W. Tong, B. Matus, R. Jesunathadas, and J. H. Zhang, "Cyclo-oxygenase-2 mediates hyperbaric oxygen preconditioning-induced neuroprotection in the mouse model of surgical brain injury," Stroke, vol. 40, no. 9, pp. 3139-3142, 2009.

[52] Q. Li, J. Li, L. Zhang, B. Wang, and L. Xiong, "Preconditioning with hyperbaric oxygen induces tolerance against oxidative injury via increased expression of heme oxygenase-1 in primary cultured spinal cord neurons," Life Sciences, vol. 80, no. 12, pp. 1087-1093, 2007.

[53] A. Kibel, A. Cavka, A. Cosic, J. R. Falck, and I. Drenjancevic, "Effects of hyperbaric oxygenation on vascular reactivity to angiotensin II and angiotensin-[1-7] in rats," Undersea and Hyperbaric Medicene Journal, vol. 39, no. 6, pp. 1053-1066, 2012.

[54] Y. Park, S. Capobianco, X. Gao, J. R. Falck, K. C. Dellsperger, and C. Zhang, "Role of EDHF in type 2 diabetes-induced endothelial dysfunction," American Journal of PhysiologyHeart and Circulatory Physiology, vol. 295, no. 5, pp. H1982H1988, 2008.

[55] L. B. Gesell, Ed., "Hyperbaric oxygen therapy indications. the hyperbaric oxygen therapy committee report," in Undersea and Hyperbaric Medical Society, Durham, NC, USA, 2008.

[56] L. B. Mamo, H. B. Suliman, B. L. Giles, R. L. Auten, C. A. Piantadosi, and E. Nozik-Grayck, "Discordant extracellular superoxide dismutase expression and activity in neonatal hyperoxic lung," American Journal of Respiratory and Critical Care Medicine, vol. 170, no. 3, pp. 313-318, 2004.

[57] J. M. Lawler and W. Song, "Specificity of antioxidant enzyme inhibition in skeletal muscle to reactive nitrogen species donors," Biochemical and Biophysical Research Communications, vol. 294, no. 5, pp. 1093-1100, 2002.

[58] C. L. Fattman, L. M. Schaefer, and T. D. Oury, "Extracellular superoxide dismutase in biology and medicine," Free Radical Biology and Medicine, vol. 35, no. 3, pp. 236-256, 2003.

[59] T. D. Oury, B. J. Day, and J. D. Crapo, "Extracellular superoxide dismutase: a regulator of nitric oxide bioavailability," Laboratory Investigation, vol. 75, no. 5, pp. 617-636, 1996.

[60] Y. Tokuda, T. Uozumi, and T. Kawasaki, "The superoxide dismutase activities of cerebral tissues, assayed by the chemiluminescence method, in the gerbil focal ischemia/reperfusion and global ischemia models," Neurochemistry International, vol. 23, no. 2, pp. 107-114, 1993.

[61] C. A. Piantadosi and L. G. Tatro, "Regional H2O2 concentration in rat brain after hyperoxic convulsions," Journal of Applied Physiology, vol. 69, no. 5, pp. 1761-1766, 1990.

[62] K. Simsek, M. Ozler, A. O. Yildirim et al., "Evaluation of the oxidative effect of long-term repetitive hyperbaric oxygen exposures on different brain regions of rats," The Scientific World Journal, vol. 2012, Article ID 849183, 7 pages, 2012.
[63] Z. Mihaljević, A. Stupin, M. Mihalj, S. Unfirer, D. Manojlović, and I. Drenjančević, "Sex differences and sex-hormones role in aortic reactivity to acethylcholine in Sprague-Dawley rats with and without streptozotocin induced diabetes mellitus," in 7th TriNet Meeting - Annual Project Review Meeting Abstract Book, Budapest, Hungary, 2016.

[64] M. T. Subbiah, B. Kessel, M. Agrawal, R. Rajan, W. Abplanalp, and Z. Rymaszewski, "Antioxidant potential of specific estrogens on lipid peroxidation," The Journal of Clinical Endocrinology \& Metabolism, vol. 77, no. 4, pp. 1095-1097, 1993.

[65] J. B. Laursen, S. Rajagopalan, Z. Galis, M. Tarpey, B. A. Freeman, and D. G. Harrison, "Role of superoxide in angiotensin II-induced but not catecholamine-induced hypertension," Circulation, vol. 95, no. 3, pp. 588-593, 1997. 


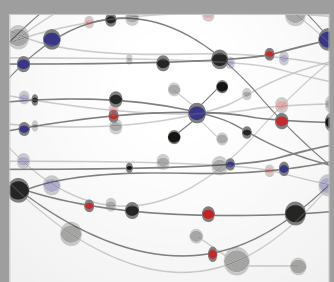

The Scientific World Journal
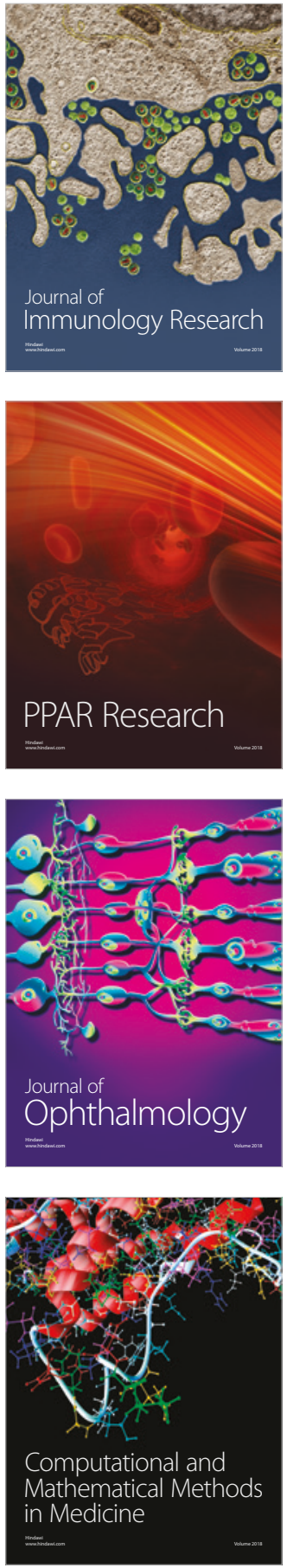

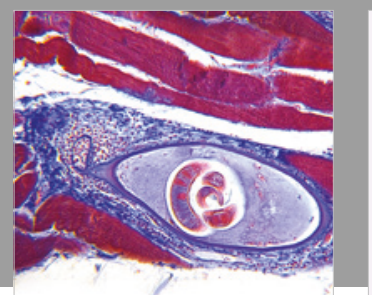

Gastroenterology Research and Practice

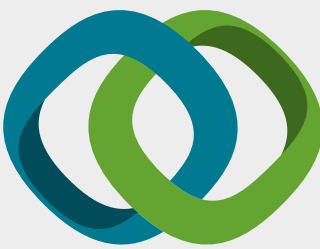

\section{Hindawi}

Submit your manuscripts at

www.hindawi.com
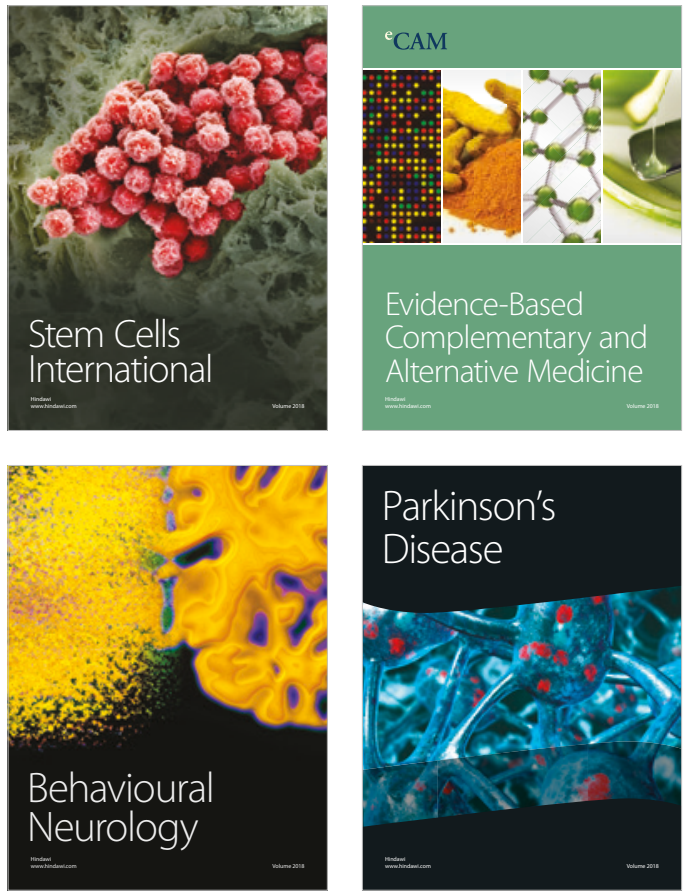

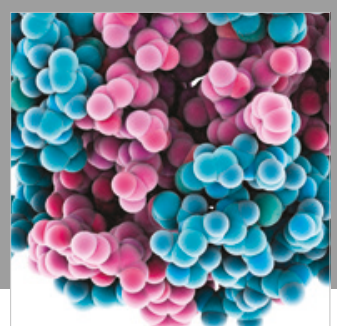

ournal of

Diabetes Research

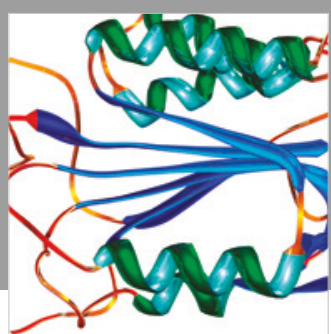

Disease Markers
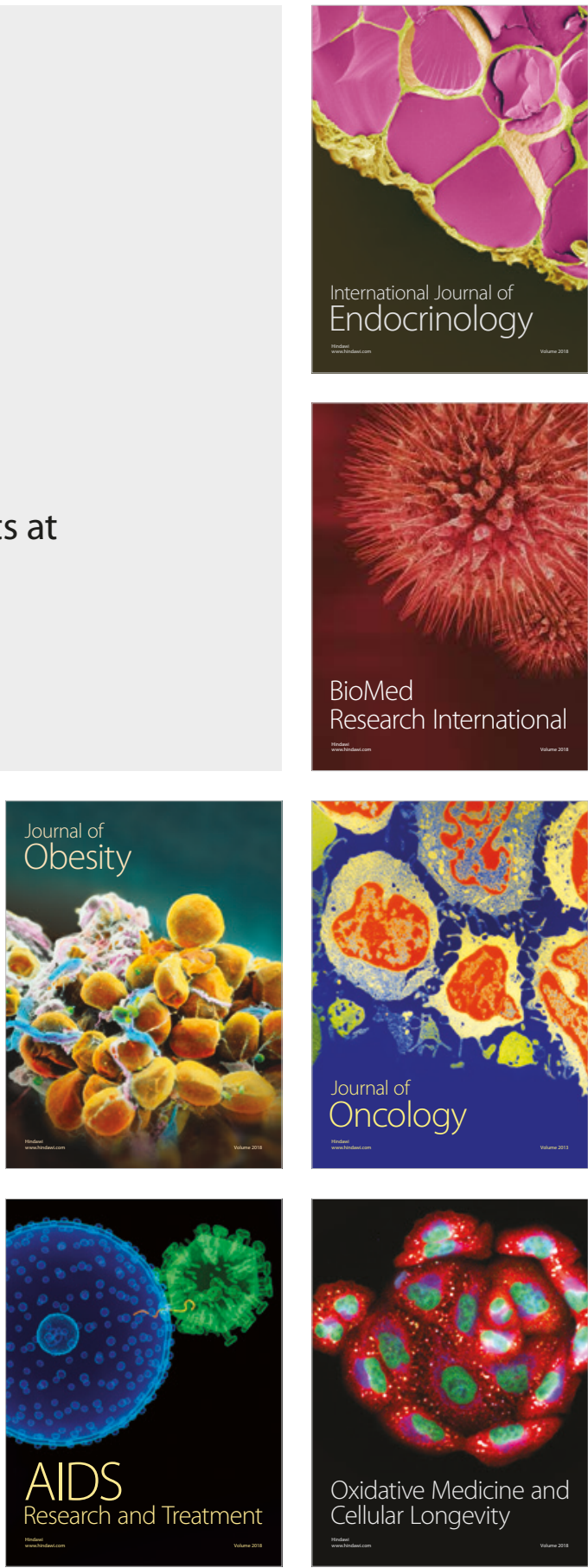